\title{
Biodiesel Sustainability: The Global Impact of Potential Biodiesel Production on the Energy-Water-Food (EWF) Nexus
}

Cheng Tung Chong ${ }^{\mathrm{a}}$, Ting Yu Loe ${ }^{\mathrm{b}}$, Kang Yao Wong ${ }^{\mathrm{b}, \mathrm{c}}$, Veeramuthu Ashokkumar ${ }^{\mathrm{d}}$, Su Shiung Lam ${ }^{\mathrm{e}}$, Wen Tong Chong $^{\mathrm{f}}$, Aiduan Borrion ${ }^{\mathrm{g}}$, Bo Tian ${ }^{\mathrm{h}}$, Jo-Han $\mathrm{Ng}^{\mathrm{b}, \mathrm{c}, *}$

${ }^{a}$ China-UK Low Carbon College, Shanghai Jiao Tong University, Lingang, Shanghai 201306, China.

${ }^{\mathrm{b}}$ Faculty of Engineering and Physical Sciences, University of Southampton Malaysia, 79200 Iskandar Puteri, Johor, Malaysia.

${ }^{\mathrm{c}}$ Energy Technology Research Group, University of Southampton, Southampton, United Kingdom.

${ }^{\mathrm{d}}$ Center of Excellence on Petrochemical and Materials technology (PETROMAT), Chulalongkorn University Pathumwan, Bangkok, Thailand

e Pyrolysis Technology Research Group, Institute of Tropical Aquaculture and Fisheries (Akuatrop), Universiti Malaysia Terengganu, 21030, Kuala Nerus, Terengganu, Malaysia.

${ }_{\mathrm{f}}^{\mathrm{f}}$ Department of Mechanical Engineering, Faculty of Engineering, University of Malaya, Kuala Lumpur, Malaysia. ${ }^{\mathrm{g}}$ Department of Civil, Environmental and Geomatic Engineering (CEGE), University College London, London, UK.

${ }^{\mathrm{h}}$ Department of Engineering, University of Cambridge, Cambridge, United Kingdom.

\begin{abstract}
A data-driven model is used to analyse the global effects of biodiesel on the energy-water-food (EWF) nexus, and to understand the complex environmental correlation. Several criteria to measure the sustainability of biodiesel and four main limiting factors for biodiesel production are discussed in this paper. The limiting factors includes water stress, food stress, feedstock quantity and crude oil price. The 155-country model covers crude oil prices ranging from USD10/bbl to USD160/bbl, biodiesel refinery costs ranging from -USD0.30/L to USD0.30/L and 45 multi-generation biodiesel feedstocks. The model is capable of ascertaining changes arising from biodiesel adoption in terms of light-duty diesel engine emissions (NO, CO, UHC and smoke opacity), water stress index (WSI), dietary energy supply (DES), Herfindahl-Hirschman index (HHI) and short-term energy security. With the addition of potential biodiesel production, the renewable energy sector of global primary energy profile can increase by $0.43 \%$, with maximum increment up to $10.97 \%$ for Malaysia. At current crude oil price of USD75/bbl and refinery cost of USD0.1/L, only Benin, Ireland and Togo can produce biodiesel profitably. The model also shows that water requirement varies non-linearly with multi-feedstock biodiesel production as blending ratio increases. Out of the 155 countries, biodiesel production is limited by feedstock quantity for 82 countries, 47 are limited by crude oil price, 20 by water stress and 6 by food stress. The results provide insights for governments to set up environmental policy guidelines, in implementing biodiesel technology as a cleaner alternative to diesel.
\end{abstract}

Keywords: Biodiesel, Sustainability, EWF nexus, Water stress, Food stress

*Corresponding Author: Jo-Han Ng (J.Ng@ soton.ac.uk), University of Southampton 


\section{Introduction}

Global primary energy demand has been increasing at a rate of $1.8 \%$ per annum since 2005 (Sharma and Singh, 2017) and reached more than 13,500 Mtoe in 2017 (BP, 2017; Enerdata, 2018), while petroleum fuel (the main transport fuel) is facing imminent depletion in 50 years based on the usage trends and proven reserves (Day and Day, 2017; BP, 2018; World Coal Association, 2018). Renewable energy sources made up the mix of the main solutions to solve this energy crisis. On the environmental aspect, renewable energy is currently the only option in the power sector that has decarbonising potential to limit global temperature rise to $2^{\circ} \mathrm{C}$ above pre-industrial level, as aimed by the 2015 Paris Agreement (Nations, 2015; Commission, 2016). The increasing energy demand and environmental concern have necessitated the use of cleaner and more sustainable energies, including biofuels such as biodiesel, bioethanol, biogas and biohydrogen (Sharma and Singh, 2017; Živković and Veljković, 2018). The European Union targeted an overall 20\% renewable energy share in energy consumption by 2020 (Commission, 2016). In 2016, the European Commission proposed to further raise its target to $27 \%$ by 2030 to meet the 2015 Paris Agreement. It was reported that only $12.9 \%$ of the global primary energy was from renewable sources in 2015 , including biofuels and wastes, geothermal, solar and hydropower (IEA, 2015).

Biodiesel has been widely studied as a renewable replacement fuel for petroleum diesel since the past few decades (Budin, Breene and Putnam, 1995; Machacon et al., 2001; Myint and El-Halwagi, 2009; Noor et al., 2016; Živković and Veljković, 2018). As a diesel substitute, biodiesel has been proven to be more beneficial in terms of emissions and renewability. However, the sustainability of biodiesel has yet to be defined. Food-crops and water are the two main consumptions during biodiesel production, while the effects of biodiesel production on the supply chains of these two resources are still unclear. As water and food form the basic human needs, the impact on these two sectors will patently influence biodiesel sustainability. In order to understand the complex interaction between biodiesel production and both water and food securities, it is necessary to consider biodiesel in the energy-water-food (EWF) nexus.

Transportation sector is the second largest energy consumer in the world at $35 \%$ of the global primary energy in 2017 (IEA, 2017) and it is one of the major sources of greenhouse gas (GHG) 
emissions (Sharma and Singh, 2017). Gasoline and diesel are respectively the first and second major transport fuels (EIA, 2017), while diesel's growth rate has outpaced that of gasoline of late (Naylor and Higgins, 2017). Correspondingly, the production growth rate of biodiesel, as diesel substitute, has been significantly higher than that of ethanol, the gasoline substitute, since 2005. In 2017, bioethanol production saw an annual increase of $2.5 \%$ while biodiesel was increasing at 9\% (REN21, 2018). Biodiesel production has increased by seven times from 2005 to 2015 and there is an expectation of another 35\% growth by 2025 (Naylor and Higgins, 2018). A range of biodiesel blendings from B2 to B8 have been achieved (and continue to grow) in 2015 by large energy consumers including Argentina, Brazil, Canada, Colombia, the EU, Indonesia, Malaysia, Thailand and the US. The use of biodiesel, either in its neat form or blended with diesel, has helped countries to improve the energy supply in both quantity and diversity.

Biodiesel is known to have better emission properties than diesel. One of the main features that differentiates biodiesel from diesel is the presence of fuel-bound oxygen. Biodiesel contains 10-15 wt.\% of oxygen, depending on the feedstock used (Canoira et al., 2010; Viola, Zimbardi and Valerio, 2011; $\mathrm{Ng}, \mathrm{Ng}$ and Gan, 2012; Silitonga, Ong, et al., 2013). The oxygen content in biodiesel results in higher flame temperature and more complete combustion in conventional CI engine (Datta and Mandal, 2017). These factors significantly affect the emission for blended biodiesel-diesel combustion. Although the addition of oxygen content from biodiesel increases the $\mathrm{CO}_{2}$ formation in biodiesel-diesel combustion, the production of biodiesel feedstocks captures $\mathrm{CO}_{2}$ via photosynthesis to offset the $\mathrm{CO}_{2}$ emitted during burning. Using life-cycle analysis, the potential to reduce $50-78 \%$ of $\mathrm{CO}_{2}$ output for biodiesel has been evidently proven (Myint and El-Halwagi, 2009; Živković and Veljković, 2018). Toxic air pollutants such as particulate matter (PM) and unburned hydrocarbons (UHCs) can be reduced by $90 \%$ and 20 $40 \%$ with the use of neat biodiesel and B20, respectively (Abbasi and Diwekar, 2014). PM forms through incomplete combustion and the burning of lubrication oil (Datta and Mandal, 2017). High temperature and pressure in the fuel-rich zone lead to formation of smoke. These two pollutants can be reduced by the fuel-bound oxygen of biodiesel in the fuel-rich zone. On the other hand, the drawback of biodiesel is the increase of thermal $\mathrm{NO}_{\mathrm{x}}$ emission (11-30\%) due to additional oxygen content and the higher flame temperature (Myint and El-Halwagi, 2009; Datta and Mandal, 2017). Despite the 
increment on $\mathrm{NO}_{\mathrm{x}}$ emission, the overall effect of biodiesel usage on the environment is considered beneficial.

Apart from the advancements in aspects of energy source and environment, studies have proven the potential of biodiesel on the near one-to-one replacement for diesel (Abbasi and Diwekar, 2014). It was found that the energy return of fossil fuel input on biodiesel production ranges from 2.5 to 3.5 . Fossil fuel is consumed during biodiesel production process such as transportation, on-farm machinery and fertiliser production. A one-to-one displacement of fossil energy with biodiesel can be achieved on a life-cycle basis. Furthermore, the similarities between diesel and biodiesel properties allow the substitutional fuel to be used without the need for engine modification. A B20 fuel can be applied directly with ease. The ultralow sulphur diesel (ULSD) standard required diesel to have sulphur content below 15ppm. Sulphur removal process will remove some natural lubricants in diesel, such as oxygen, nitrogen and aromatics (Hu, Zhang and Li, 2017). (Muñoz et al., 2011) reported that ULSD fuel lubricity can be improved to $338 \mu \mathrm{m}$ wear scar diameter (WSD) with as low as $100 \mathrm{ppm}$ biodiesel addition, whereas pure diesel fuel with 10ppm sulphur content would show a WSD of more than 500ๆm (Nicolau et al., 2014). Another study showed that biodiesels with lower mono-saturation level exhibit better friction modifier effect for boundary and elasto-hydrodynamic lubrication regimes while reducing the load carrying capacity along mixed lubrication regime (Hamdan et al., 2017). Coconut biodiesel, with the lowest mono-saturation level, has the best friction modifier effect among the tested fuels while the worst load carrying capacity. On the other hand, soybean biodiesel would be a better bio-lubricant/additive, showing more balanced lubrication properties. The improved lubrication would lead to better engine operation, in terms of efficiency and lifespan (Myint and El-Halwagi, 2009).

Besides the benefits of using biodiesel as a fuel, having renewable and sustainable sources is a potent criterion for a sustainable production. Different possible sources for biodiesel production have been explored. The three common feedstocks include edible oils (vegetable oil and animal fat), nonedible oil (such as waste cooking oil, jatropha oil, camelina oil) and microalgae, which respectively represent the first, second and third generation of biodiesel feedstock (Elms and El-Halwagi, 2010; Mata et al., 2011; Abbasi and Diwekar, 2014; Sharma and Singh, 2017; Hasan and Avami, 2018; Nabi and Rasul, 2018). All of these sources are considered renewable, however, there are different issues 
associated with each of them. First-generation biodiesel is the most common and its production often leads to the well-known food-fuel debate, with influences on both the supply and prices (Naylor and Higgins, 2018). Non-edible second-generation biodiesel feedstocks can be grown on non-arable land, although lands for food production can be saved, it still requires more study for the feasibility and productivity (Hasan and Avami, 2018). Microalgal biodiesel has high production and contributes to lower emissions, while the water consumption could be more than double of the first and second generation, and technologies involving cultivation, oil extraction and harvesting need to be further improved (Sharma and Singh, 2017).

An analytical predicting study has arisen from the concerns of food security, emission and water requirement for biodiesel as a renewable energy in Iran (Hasan and Avami, 2018). As the world $10^{\text {th }}$ largest GHG producer in 2012, the country has been taking actions to mitigate its carbon footprint. The authors analysed three scenarios for biodiesel production in the water-energy-emission nexus with the aim to obtain optimal pathways to satisfy the B2 (2\% biodiesel blend) energy demand. In order to not disturb the food security, non-edible second and third generation feedstocks like jatropha and microalgae are chosen for biodiesel production in each scenario. The cost, emission and water requirement throughout the production were respectively minimised in the three scenarios. It is reported that, in Iran, GHG emission can be reduced by the use of biodiesel (especially microalgal biodiesel) while water consumption during biodiesel production will limit the available water supply for other human uses.

Food security can be correlated to the arable land (Irabien and Darton, 2016). The land can be seen as a medium to store, convert and provide energy for food production. A research analysed the food-energy nexus through the case study of the on-farm energy generation in Miyagi, Japan (Cuberos Balda, Furubayashi and Nakata, 2017). Miyagi is a prefecture with the largest abandoned land (9720 ha) in Japan since the 2011 earthquake. The case study proposed to utilise the abandoned land with selfsufficient farms by growing crops for food and biofuel production. By setting the priority to meet the local food demand and using the surplus land to produce biofuel feedstocks, there could be a net improvement in both food security and energy security. The research showed that $5247 \mathrm{~kL} / \mathrm{year}$ of bioethanol can potentially be produced to substitute current gasoline demand with E5 fuel (5\% 
bioethanol and 95\% gasoline) in buses, regular cargo and 53\% of small cargo in Miyagi. The utilisation of energy self-sufficient farms would bring multiple positive impacts, including reduction in the dependency on fossil fuels and food import, job generation and increase in food security and local fuel access.

(Gilron, 2014) mentioned the typical example of water-energy nexus for power generation and water desalination at coastal area. As energy production consumes water and at the same time water treatment uses energy, water has been both the sink and source of energy. Energy production has become an increasingly large water consumer, and biodiesel production is no exemption. Another study about EWF nexus also portrayed the interlinkage of the three elements via a greenhouse tomato production case study (Irabien and Darton, 2016). Fresh water is required in cultivating crops (whether it is food- or energy-crop) as well as in energy production and conservation; energy is used in water treatment, food processing and transportation of both water and food; and crops can be converted to food and fuel while agriculture can be competing for land use with water system. The water footprint for each biofuel production varies significantly with the feedstock used as well as the production region (Xie et al., 2017). Selections for feedstocks and production pathways according to local conditions, such as climate and crop yield, will play important roles in the energy-water relationship. According to (Irabien and Darton, 2016), in order to achieve a sustainable EWF system, all three elements must be able to provide availability, accessibility and utilisation (AAU) for human well-being, while assuring the extent and diversity of the ecosystems on the planet in space and time.

Researches have shown the capability of biodiesel as replacement fuel for diesel. Many studies have tried to understand the correlation between energy production and basic natural resources such as water and food. In this study, a data-driven model is developed to investigate the potential and the global impact of biodiesel production on the EWF nexus. Two main categories of biodiesel feedstocks are considered: edible oil and non-edible oil, which respectively represents the first and second-generation biodiesel feedstock. As the first-generation feedstock is dominant in the current biodiesel production, the report focused on the potential effect of the first generation biodiesel on various aspects, including the limiting factors in the EWF nexus, emissions, energy diversity and energy security. Generation replacement of biodiesel feedstock is also considered in term of the plausible arable land saving. The 
results of this study can serve as a reference for governments to set up policies regarding to biodiesel production in each country.

\section{Methodology}

In this data-driven model, potential biodiesel production of 155 countries are evaluated under 31 crude oil prices and 13 refinery costs. The crude oil price ranges from USD10/bbl to USD160/bbl with an interval of USD5/bbl, while the refinery cost is set from -USD0.30/L to USD0.30/L with a USD0.05/L interval. There are 14 first-generation biodiesel feedstocks selected, including coconut, cottonseed, groundnut, kapok, maize, palm, olive, palm kernel, rapeseed, safflower, sesame, soybean, sunflower and rice bran (Saladini et al., 2016). Feedstock data, including export quantity (FAO, 2016b), export value (FAO, 2016c) and crop yield (FAO, 2016a), is taken from FAOSTAT for countries all over the world. The 155 countries are then selected due to the completeness of the dataset.

Thailand, Indonesia and Malaysia are the three countries that are focused in this study. Thailand has comparatively spread feedstocks for biodiesel production, including palm, palm kernel and soybean. Indonesia has potential multi-feedstock biodiesel production capability that heavily depends on palm. Biodiesel production in Malaysia, on the other hand, can be fully relied on one single feedstock, which is palm. Thailand, Indonesia and Malaysia represent countries that have potential biodiesel production with lightly skewed multi-feedstock, heavily skewed multi-feedstock and monopolised feedstock in this study, respectively. Throughout the economic setup of the model, 10 feedstocks could be profitable in biodiesel production. This includes coconut, cottonseed, groundnut, maize, palm, palm kernel, rapeseed, safflower, soybean and sunflower. Additionally, second generations such as camelina, jatropha, jojoba, karanja, kenaf, linseed, mahua, moringa and tumba were also evaluated.

\section{Potential biodiesel production}

\subsection{First-Generation Biodiesel}

A total of 14 first-generation biodiesel feedstocks are included in this study. The properties of these vegetable oils are presented in Table 1, whereas Table 2 lists out the fuel properties of the 14 
biodiesels feedstocks. The oil density is used to calculate the conversion of vegetable oil into biodiesel. The cetane number, kinematic viscosity, carbon residue, oxygen content and density of biodiesel are used to predict the engine-out emissions for light-duty diesel engines.

Table 1: Properties of edible vegetable oil as first-generation biodiesel feedstock.

\begin{tabular}{|c|c|c|c|c|}
\hline Feedstock & $\begin{array}{l}\text { Oil } \\
\text { Content } \\
(\mathrm{wt} \%)\end{array}$ & $\begin{array}{l}\text { Oil } \\
\text { Density } \\
(\mathrm{kg} / \mathrm{L})\end{array}$ & $\begin{array}{l}\text { Energy } \\
\text { Content } \\
(\mathrm{MJ} / \mathrm{kg})\end{array}$ & Ref. \\
\hline Coconut & 64 & 0.918 & 35.00 & $\begin{array}{l}\text { (Machacon et al., 2001; Karmakar, } \\
\text { Karmakar and Mukherjee, 2010) }\end{array}$ \\
\hline Palm kernel & 54.5 & 0.922 & 38.03 & $\begin{array}{l}\text { (Chuah et al., 2006; Benjapornkulaphong, } \\
\text { Ngamcharussrivichai and Bunyakiat, 2009; } \\
\text { Karmakar, Karmakar and Mukherjee, 2010) }\end{array}$ \\
\hline Palm & 45 & 0.918 & 40.14 & $\begin{array}{l}\text { (Agarwal, 2007; Karmakar, Karmakar and } \\
\text { Mukherjee, 2010; Kumar, Varun and } \\
\text { Chauhan, 2013) }\end{array}$ \\
\hline Cottonseed & 21.5 & 0.915 & 39.65 & $\begin{array}{l}\text { (Altin, Cetinkaya and Yucesu, 2001; } \\
\text { Agarwal, 2007; Karmakar, Karmakar and } \\
\text { Mukherjee, 2010) }\end{array}$ \\
\hline Rice bran & 19 & 0.919 & 39.50 & $\begin{array}{l}\text { (Machacon et al., 2001; Karmakar, } \\
\text { Karmakar and Mukherjee, 2010) }\end{array}$ \\
\hline Groundnut & 50 & 0.903 & 39.80 & $\begin{array}{l}\text { (Agarwal, 2007; Karmakar, Karmakar and } \\
\text { Mukherjee, 2010; Verma and Sharma, } \\
\text { 2016) }\end{array}$ \\
\hline Kapok & 26.5 & 0.921 & 39.56 & $\begin{array}{l}\text { (Agarwal, 2007; Senthil Kumar, Senthil } \\
\text { Kumar and Annamalai, 2015) }\end{array}$ \\
\hline Soybean & 17.5 & 0.914 & 39.62 & $\begin{array}{l}\text { (Altin, Cetinkaya and Yucesu, 2001; } \\
\text { Agarwal, 2007; Karmakar, Karmakar and } \\
\text { Mukherjee, 2010) }\end{array}$ \\
\hline Sesame & 50 & 0.913 & 39.30 & $\begin{array}{l}\text { (Whittington, 2006; Sinha, Agarwal and } \\
\text { Garg, 2008; Russo et al., 2012) }\end{array}$ \\
\hline Olive & 57.5 & 0.925 & 37.00 & $\begin{array}{l}\text { (Karmakar, Karmakar and Mukherjee, } \\
\text { 2010; Kumar, Varun and Chauhan, 2013) }\end{array}$ \\
\hline Maize & 48 & 0.910 & 39.50 & $\begin{array}{l}\text { (Sinha, Agarwal and Garg, 2008; } \\
\text { Karmakar, Karmakar and Mukherjee, 2010; } \\
\text { Verma and Sharma, 2016) }\end{array}$ \\
\hline Sunflower & 30 & 0.916 & 39.53 & $\begin{array}{l}\text { (Altin, Cetinkaya and Yucesu, 2001; Sinha, } \\
\text { Agarwal and Garg, 2008; Karmakar, } \\
\text { Karmakar and Mukherjee, 2010) }\end{array}$ \\
\hline
\end{tabular}




\begin{tabular}{lcccl}
\hline Rapeseed & 42 & 0.912 & 37.62 & (Altin, Cetinkaya and Yucesu, 2001; \\
& & & & Agarwal, 2007; Karmakar, Karmakar and \\
& & & Mukherjee, 2010) \\
Safflower & 40 & \multirow{2}{*}{0.914} & 39.50 & (Agarwal, 2007; Onay, 2007; Singh and \\
& & & & Singh, 2010) \\
\hline
\end{tabular}

Table 2: Fuel properties of first-generation biodiesel.

\begin{tabular}{|c|c|c|c|c|c|c|c|}
\hline Feedstock & $\begin{array}{l}\text { Biodiesel } \\
\text { Density } \\
(\mathrm{kg} / \mathrm{L})\end{array}$ & $\begin{array}{l}\text { Energy } \\
\text { Content } \\
(\mathrm{MJ} / \mathrm{kg})\end{array}$ & $\begin{array}{l}\text { Cetane } \\
\text { Number }\end{array}$ & $\begin{array}{l}\text { Kinematic } \\
\text { Viscosity } \\
(\mathrm{mm} 2 / \mathrm{s})\end{array}$ & $\begin{array}{l}\text { Carbon } \\
\text { Residue } \\
(\mathrm{wt} \%)\end{array}$ & $\begin{array}{l}\text { Oxygen } \\
\text { Content } \\
(\mathrm{wt} \%)\end{array}$ & Ref. \\
\hline Coconut & 0.870 & 35.20 & 65.80 & 2.70 & 0.001 & 15.10 & $\begin{array}{l}\text { (Hoekman et al., 2012; } \\
\mathrm{Ng}, \mathrm{Ng} \text { and Gan, 2012) }\end{array}$ \\
\hline Palm kernel & 0.870 & 36.50 & 56.50 & 2.80 & 0.087 & 13.36 & $\begin{array}{l}\text { (Benjapornkulaphong, } \\
\text { Ngamcharussrivichai } \\
\text { and Bunyakiat, 2009; } \\
\text { Viola, Zimbardi and } \\
\text { Valerio, 2011) }\end{array}$ \\
\hline Palm & 0.874 & 37.30 & 67.50 & 4.40 & 0.020 & 11.90 & $\begin{array}{l}\text { (Hoekman et al., 2012; } \\
\text { Ng, Ng and Gan, 2012) }\end{array}$ \\
\hline Cottonseed & 0.879 & 38.18 & 53.30 & 4.70 & 0.020 & 11.13 & $\begin{array}{l}\text { (Rao et al., 2011; Viola, } \\
\text { Zimbardi and Valerio, } \\
\text { 2011; Giakoumis, 2013) }\end{array}$ \\
\hline Rice bran & 0.881 & 38.05 & 56.30 & 4.70 & 0.230 & 11.00 & $\begin{array}{l}\text { (Lin et al., 2009; Viola, } \\
\text { Zimbardi and Valerio, } \\
\text { 2011; Giakoumis, 2013) }\end{array}$ \\
\hline Groundnut & 0.883 & 38.05 & 54.90 & 4.77 & 0.087 & 10.87 & $\begin{array}{l}\text { (Viola, Zimbardi and } \\
\text { Valerio, 2011; } \\
\text { Giakoumis, 2013) }\end{array}$ \\
\hline Kapok & 0.877 & 39.40 & 57.20 & 4.61 & 0.029 & 11.04 & $\begin{array}{l}\text { (Silitonga, Masjuki, et } \\
\text { al., 2013; Silitonga, } \\
\text { Ong, et al., 2013; Senthil } \\
\text { Kumar, Senthil Kumar } \\
\text { and Annamalai, 2015) }\end{array}$ \\
\hline Soybean & 0.885 & 37.00 & 51.00 & 4.00 & 0.005 & 11.50 & $\begin{array}{l}\text { (Hoekman et al., 2012; } \\
\mathrm{Ng}, \mathrm{Ng} \text { and Gan, 2012) }\end{array}$ \\
\hline Sesame & 0.867 & 40.40 & 50.48 & 4.20 & 0.039 & 10.92 & $\begin{array}{l}\text { (Karmakar, Karmakar } \\
\text { and Mukherjee, 2010; } \\
\text { Viola, Zimbardi and } \\
\text { Valerio, 2011; Sarve, }\end{array}$ \\
\hline
\end{tabular}




\begin{tabular}{|c|c|c|c|c|c|c|c|}
\hline & & & & & & & $\begin{array}{l}\text { Sonawane and Varma, } \\
\text { 2015) }\end{array}$ \\
\hline Olive & 0.881 & 37.29 & 58.90 & 5.05 & 0.220 & 10.92 & $\begin{array}{l}\text { (Viola, Zimbardi and } \\
\text { Valerio, 2011; } \\
\text { Giakoumis, 2013; Noor } \\
\text { et al., 2016) }\end{array}$ \\
\hline Maize & 0.882 & 38.60 & 52.50 & 4.32 & 0.087 & 10.97 & $\begin{array}{l}\text { (Viola, Zimbardi and } \\
\text { Valerio, 2011; } \\
\text { Giakoumis, 2013) }\end{array}$ \\
\hline Sunflower & 0.883 & 37.80 & 51.90 & 4.53 & 0.050 & 10.92 & $\begin{array}{l}\text { (Sinha, Agarwal and } \\
\text { Garg, 2008; Viola, } \\
\text { Zimbardi and Valerio, }\end{array}$ \\
\hline Rapeseed & 0.882 & 37.63 & 54.10 & 4.63 & 0.010 & 10.87 & $\begin{array}{l}\text { 2011; Giakoumis, 2013) } \\
\text { (Schober and } \\
\text { Mittelbach, 2004; Viola, } \\
\text { Zimbardi and Valerio, } \\
\text { 2011; Giakoumis, 2013) }\end{array}$ \\
\hline Safflower & 0.884 & 38.15 & 51.80 & 4.10 & 0.087 & 10.90 & $\begin{array}{l}\text { (Viola, Zimbardi and } \\
\text { Valerio, 2011; } \\
\text { Giakoumis, 2013) }\end{array}$ \\
\hline
\end{tabular}


a)

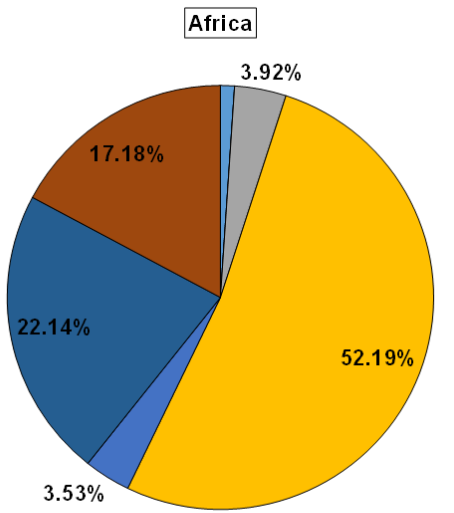

d)

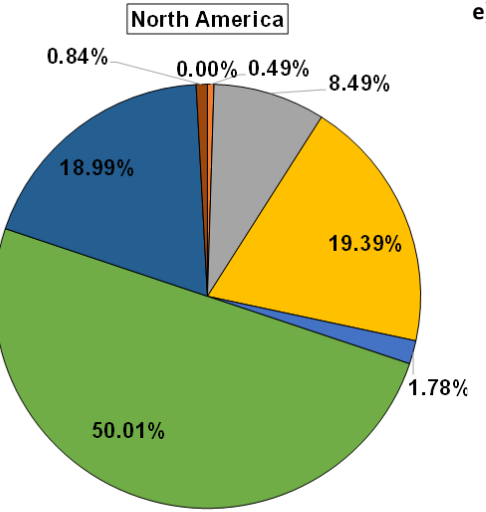

b)

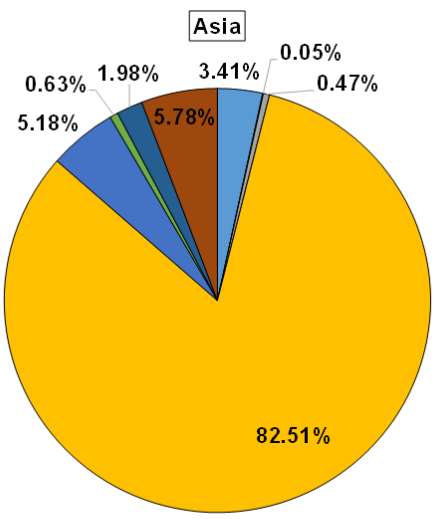

)

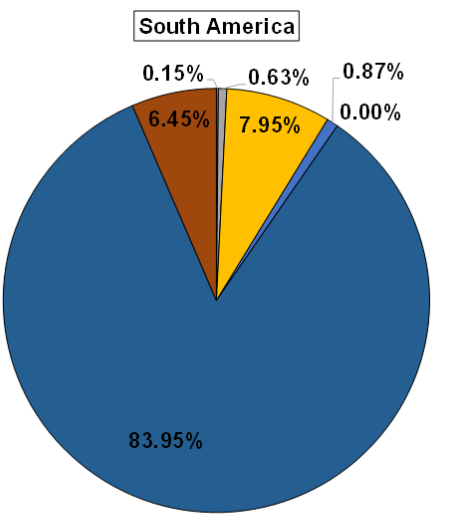

c)

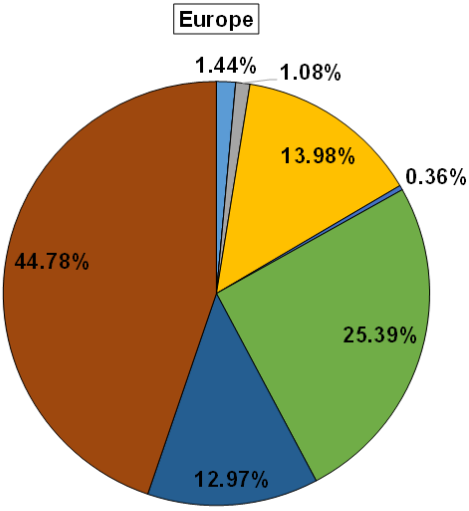

f)

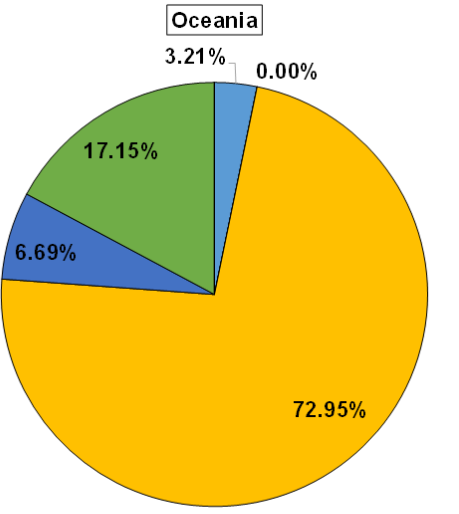

$\square$ Oil, coconut (copra) $\square$ Oil, cottonseed $\square$ Oil, maize

$\square$ Oil, palm

$\square$ Oil, palm kerne

$\square$ Oil, rapeseed

$\square$ Oil, soybean 口Oil, sunflower

Figure 1: Proportion of potential first-generation feedstock at continental level for (a) Africa (b) Asia (c) Europe (d) North America (e) South America (f) Oceania.

Figure 1 shows the proportion of potential first-generation feedstock at continental level based on the amount of oil extracted. From it, the two main potential biodiesel feedstocks in the world are oil palm and soybean. Both feedstocks are oilseed crops, with the highest oil production worldwide. On continent basis, the potential biodiesel that can be produced from the feedstocks selected in this study for Asia and Oceania will be monopolised by palm with the proportion of $83 \%$ and $73 \%$, respectively. Africa has $52 \%$ of its biodiesel feedstocks contributed from palm. In South America, soybean is the dominant feedstock with a proportion of $84 \%$, whereas in North America the major feedstock is rapeseed with a proportion of 50\%. However, the variations of feedstock in Europe is relatively wellspread. On country basis, as shown in Figure 2, out of the 84 countries that can potentially produce biodiesel, palm would be the dominant feedstock in 23 countries, rapeseed in 17 countries, sunflower 
in 14 countries and 7 other feedstocks spread among 30 countries. The potential feedstock quantity at this point shows the upper limits for conversion into biodiesel. In reality, it will face competition from other sectors like the food industry and intra-sector cross-usage for other sustainable liquid biofuels.

The current biodiesel production shows that 13 major biodiesel-producing countries with a minimum biodiesel production of 10,000 barrels per day are the United States, Brazil, Indonesia, Germany, Argentina, France, Spain, Thailand, Poland, Singapore, Belgium, the Netherlands and Colombia (EIA, 2016). With the potential feedstocks, these countries have immense potential to increase the production of biodiesel by a large volume. For instance, countries such as Indonesia, Malaysia, Argentina, Ukraine, Canada, the Netherlands, Russian Federation, Germany, the United States, Spain and Brazil can potentially produce $1 \times 10^{9}$ litres of biodiesel per annum.

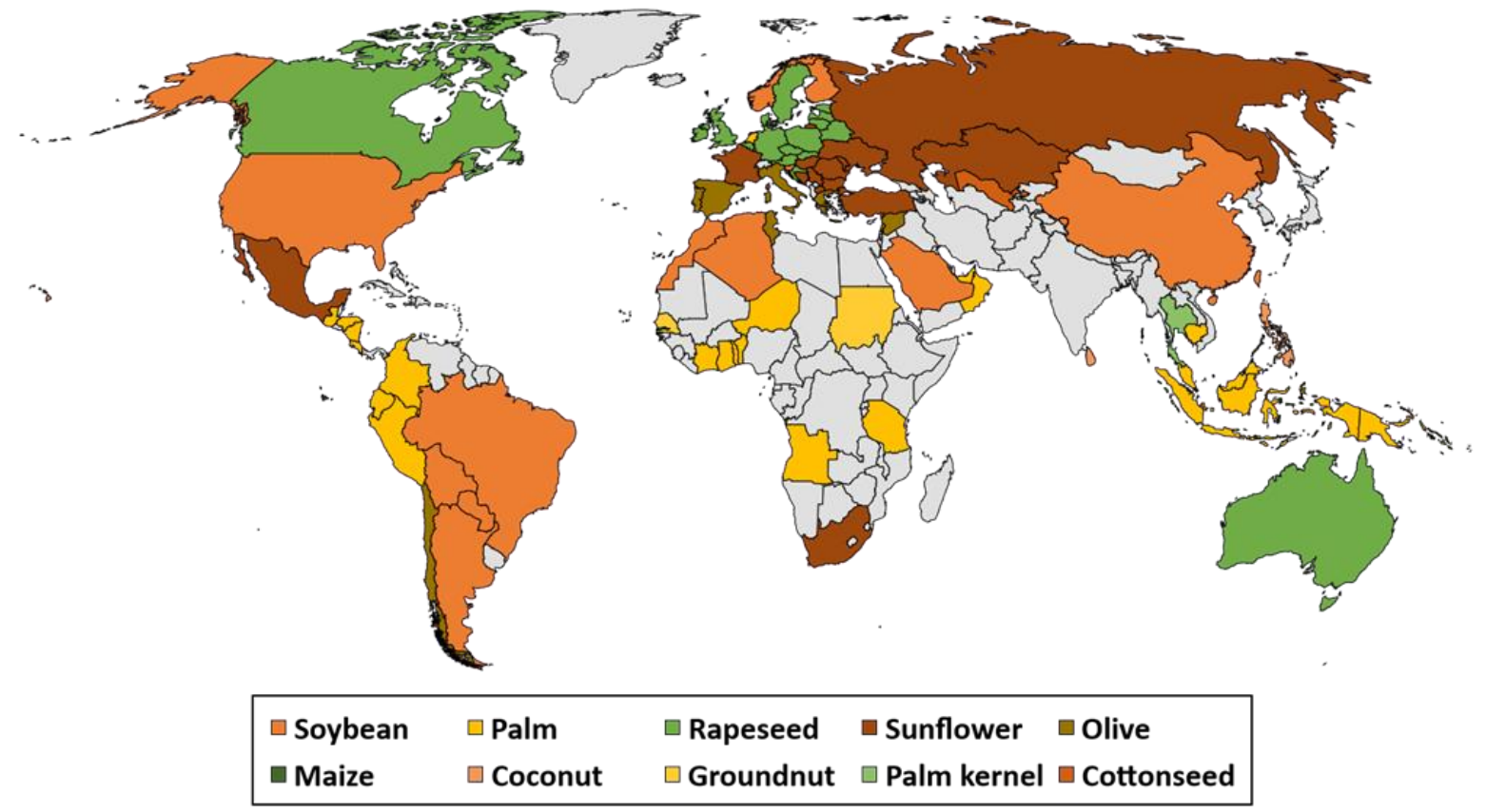

Figure 2: Potential dominant first-generation biodiesel feedstock of each country.

Potential biodiesel volume $\left(P B V_{i j}\right)$ for each feedstock and country is calculated:

$$
\begin{aligned}
& P B V_{i j}=L V_{i j} \times C R \\
L V_{i j}= & \frac{E Q_{i j} \times 1000}{O D_{i}}
\end{aligned}
$$


where $L V_{i j}$ is the lipid volume of each of the potential biodiesel feedstocks in different countries, and $C R(0.98)$ is the volumetric conversion ratio from oil to biodiesel (Johnston and Holloway, 2007; O'Keeffe et al., 2017) $E Q_{i j}$ is the export quantity of each feedstock, and $O D_{i}$ is the oil density. A minimum threshold value of 10,000 tonnes has been set for the export quantity. Any export quantity of vegetable oils that is lower than the threshold is considered to be inadequate for the potential biodiesel production. The threshold value is based on a generic biodiesel plant with a capacity of 10 million litres per annum (USDA, 2017). The export quantity which reaches the threshold value is used in the calculation of the potential biodiesel production.

By summing up the total potential biodiesel production, $T P B V_{j}$ with the current biodiesel production, $C B V_{j}$, the total biodiesel volume, $T B V$ of a country can be obtained. Figure 3 shows the total biodiesel volume against the current annual diesel consumption of each country (EIA, 2014). The countries which locate above the B100 line indicate that the total biodiesel volume can fully replace the current diesel consumption on volumetric basis. The B10 and B1 lines respectively represent the total biodiesel volume of $10 \%$ and $1 \%$ diesel replacement. The only country which is capable to produce sufficient biodiesel to totally replace diesel is Malaysia, followed by Indonesia with a volumetric blending ratio of $88 \%$. There are another 25 countries that can potentially achieve B10, including nine European countries such as Ukraine, the Netherlands, Lithuania and Hungary, whereas 45 countries can reach the B1 line. The majority of European countries are scattered between the B1 and B10 lines, this shows that European countries have potential to add biodiesel into their energy mix. 


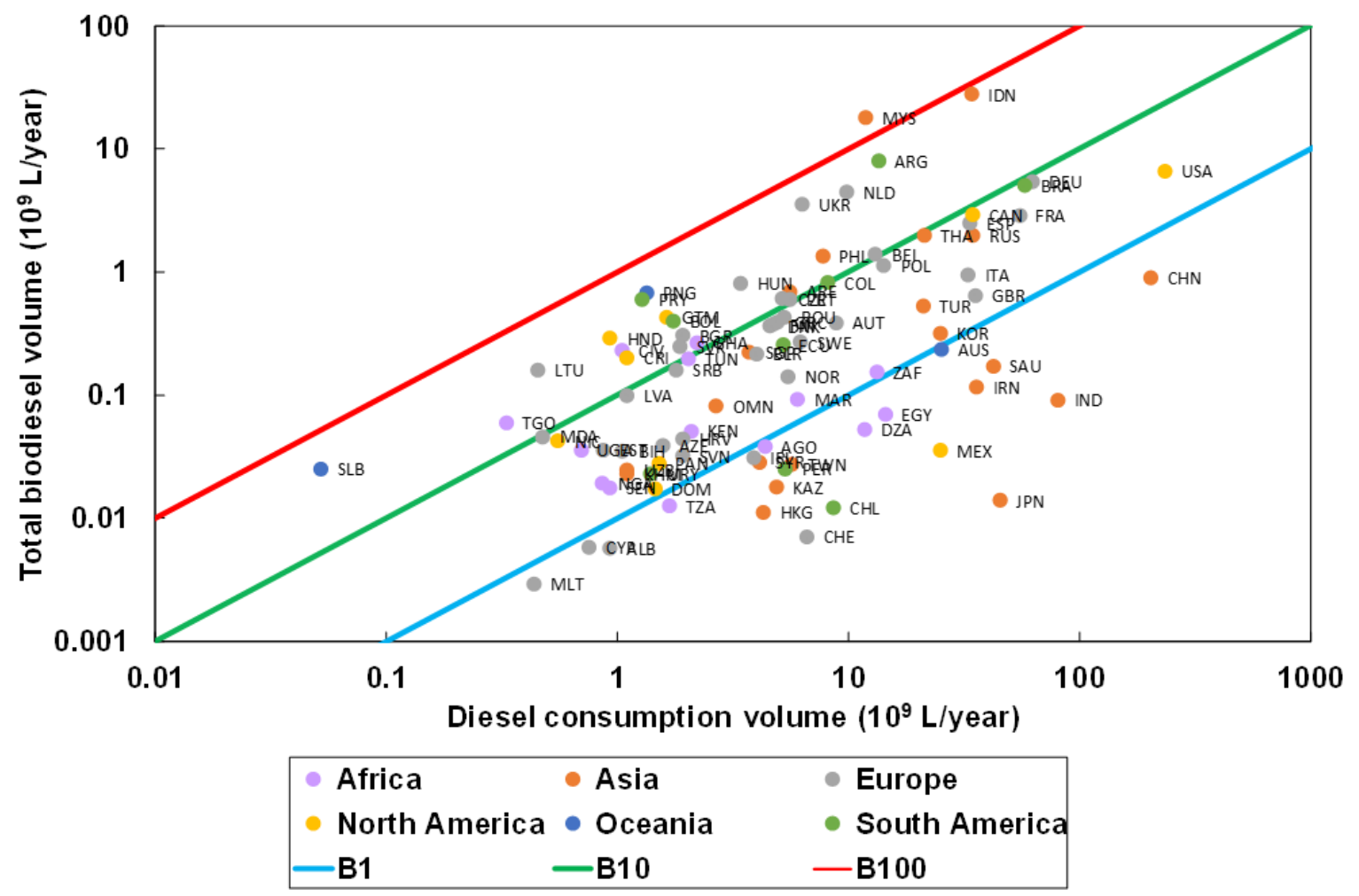

Figure 3: Total first-generation biodiesel volume against diesel consumption volume of all countries with potential feedstock, with lines representing level of blending ratio (B1, B10 and B100).

Figure 4 shows the primary energy profile of the world and Malaysia, with and without the potential biodiesel production (IEA, 2015). At present, the total global renewable energy is $72.12 \times 10^{12}$ MJ. By introducing the total potential biodiesel volume from all countries into the energy market, the value can be increased to $74.90 \times 10^{12}$ MJ. Currently in Malaysia, the energy from biofuels and waste is $2.34 \%$ of the total primary energy, but with the potential biodiesel volume of $15.9 \times 10^{9}$ litres, the value can be raised to $13.45 \%$. Hence, the energy sources in Malaysia could become more diverse, at the same time, decreasing the dependency on fossil fuels. 


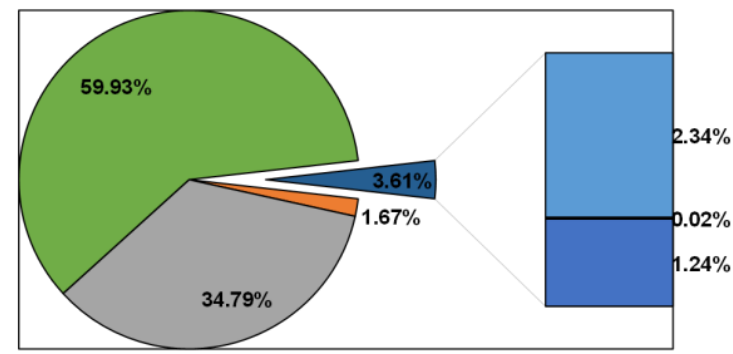

c)

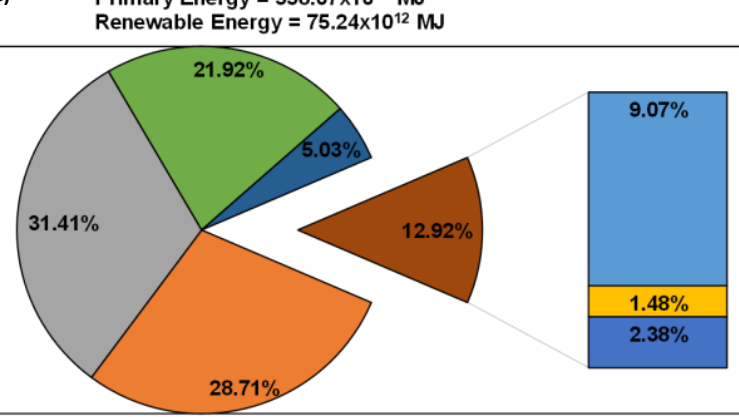

Primary Energy $=4.63 \times 10^{12} \mathrm{MN}$

Renewable Energy $=7.11 \times 10^{12} \mathrm{M}$

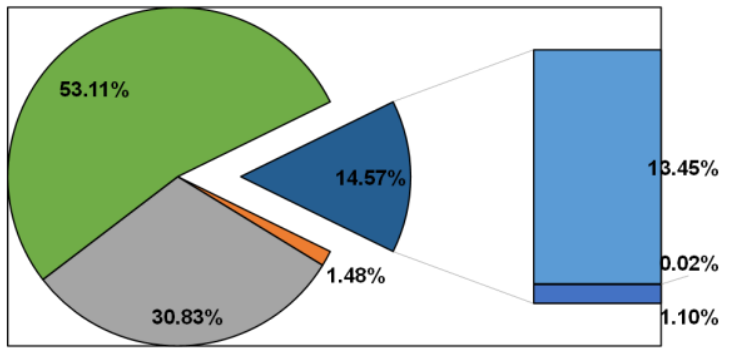

d) Primary Energy $=560.59 \times 10^{12} \mathrm{MJ}$ Renewable Energy $=77.87 \times 10^{12} \mathrm{MW}$

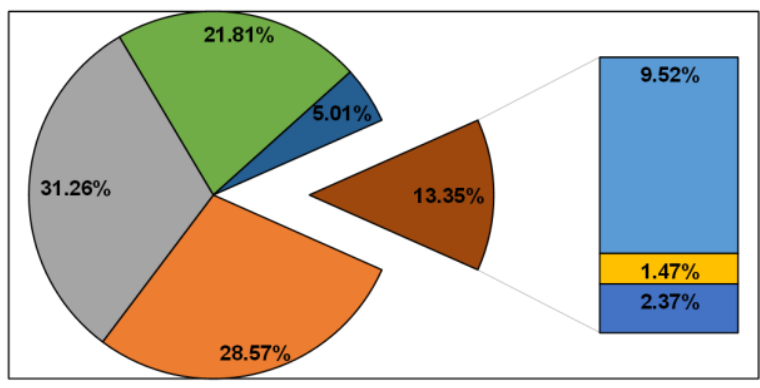

$\square$ Biofuels and waste $\square$ Coal

$\square$ Geothermal \& solar $\square$ Hydro -Nuclear

Figure 4: Primary energy profile for a) Malaysia, current condition b) Malaysia, with potential biodiesel volume c) world, current condition d) world, with potential biodiesel volume.

\subsection{Second-generation biodiesel - replacement}

Second-generation biodiesel is produced from non-food biomass (Saladini et al., 2016). The oils produced will not affect the supply in food market. In this model, 10 second-generation biodiesel feedstocks, namely jatropha, camelina, castor bean, tumba, linseed, jojoba, kenaf, karanja, moringa, and mahua, are evaluated. Feedstock with the most crop yield available natively in each of the 130 countries evaluated for second-generation biodiesel will be selected as the potential dominant second-generation feedstock (as shown in Figure 5). Jatropha is a superior feedstock as it is the potential dominant feedstock in 62 out of 130 countries. Jatropha can be easily cultivated without intensive care in lands that are not suitable for food crops, thus it has wider distribution in the world. Furthermore, camelina is also an outstanding feedstock in almost all European countries (Gui, Lee and Bhatia, 2008). 


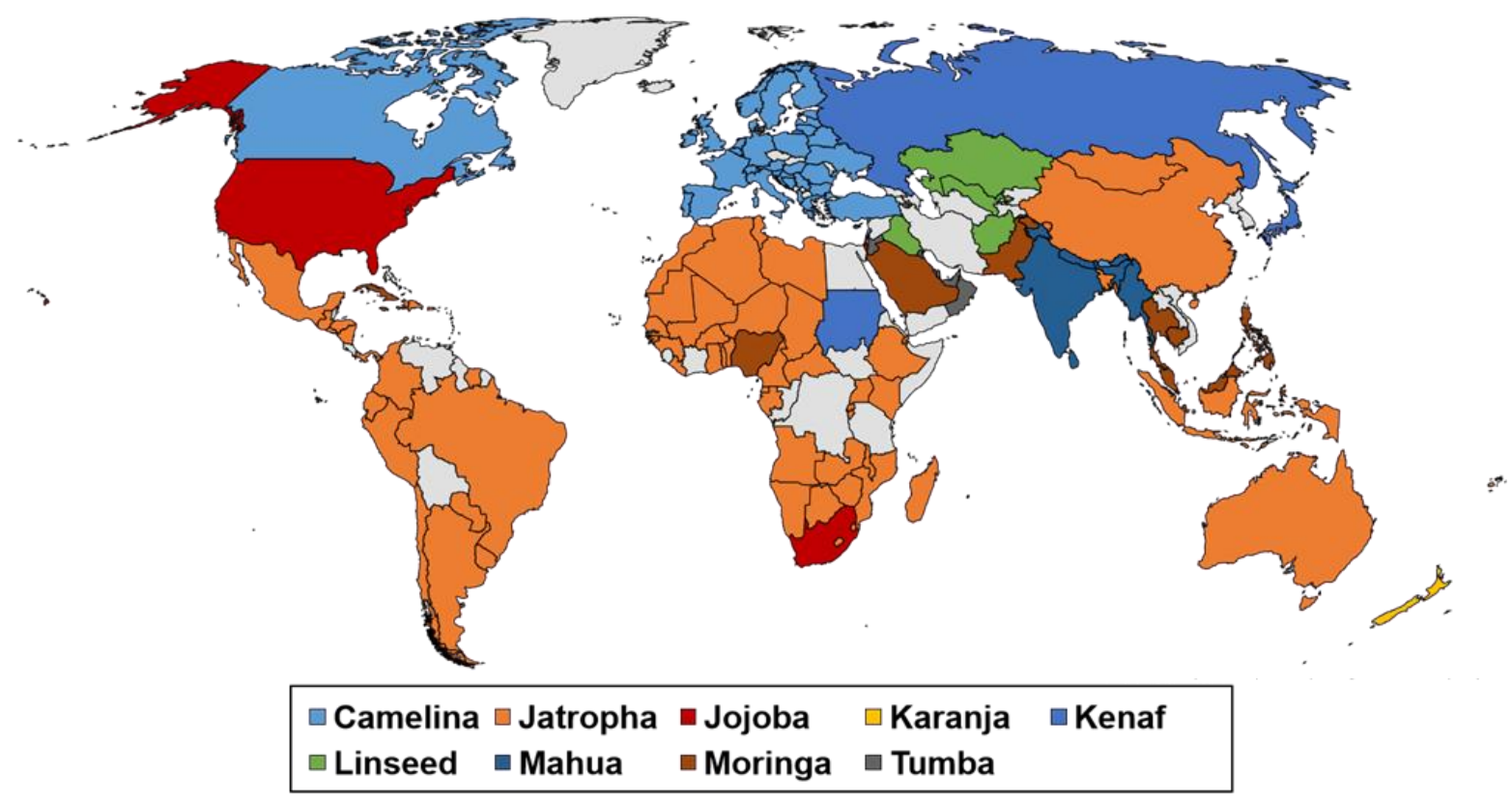

Figure 5: Potential dominant second-generation biodiesel feedstock of each country.

The total plantation area of first-generation feedstock $\left(T P A_{j}\right)$ to produce the total potential biodiesel volume is determined as follow:

$$
T P A_{j}=\sum_{i} \frac{E Q_{i j} \times 1000}{C Y_{i j} \times O C_{i}}
$$

where $C Y_{i j}$ and $O C_{i}$ are the crop yield and oil content of the feedstocks, respectively. The crop yield of each first-generation feedstock which is obtained from FAOSTAT varies for different countries (FAO, 2016a).

The land area required by second-generation feedstocks $\left(S P A_{j}\right)$ to produce the same volume of total potential biodiesel volume is calculated:

$$
S P A_{j}=\frac{T P B V_{j} \times O D_{i}}{C Y_{i} \times O C_{i} \times C R}
$$

The land area saved by replacing first-generation feedstock with second-generation feedstock, $T A S S_{j}$ can then be equated by deducting $S P A$ from $T P A$. Figure 6 shows the land area saved by replacing the first-generation feedstock with second-generation feedstock in seven countries. More than 15 million hectares of plantation area can be saved in Indonesia and Malaysia, by replacing all the firstgeneration feedstocks with jatropha and moringa, respectively. Second-generation biodiesel feedstocks 
can be planted in non-arable lands and do not compete for lands with food crops, making them good candidates to replace first-generation feedstocks.

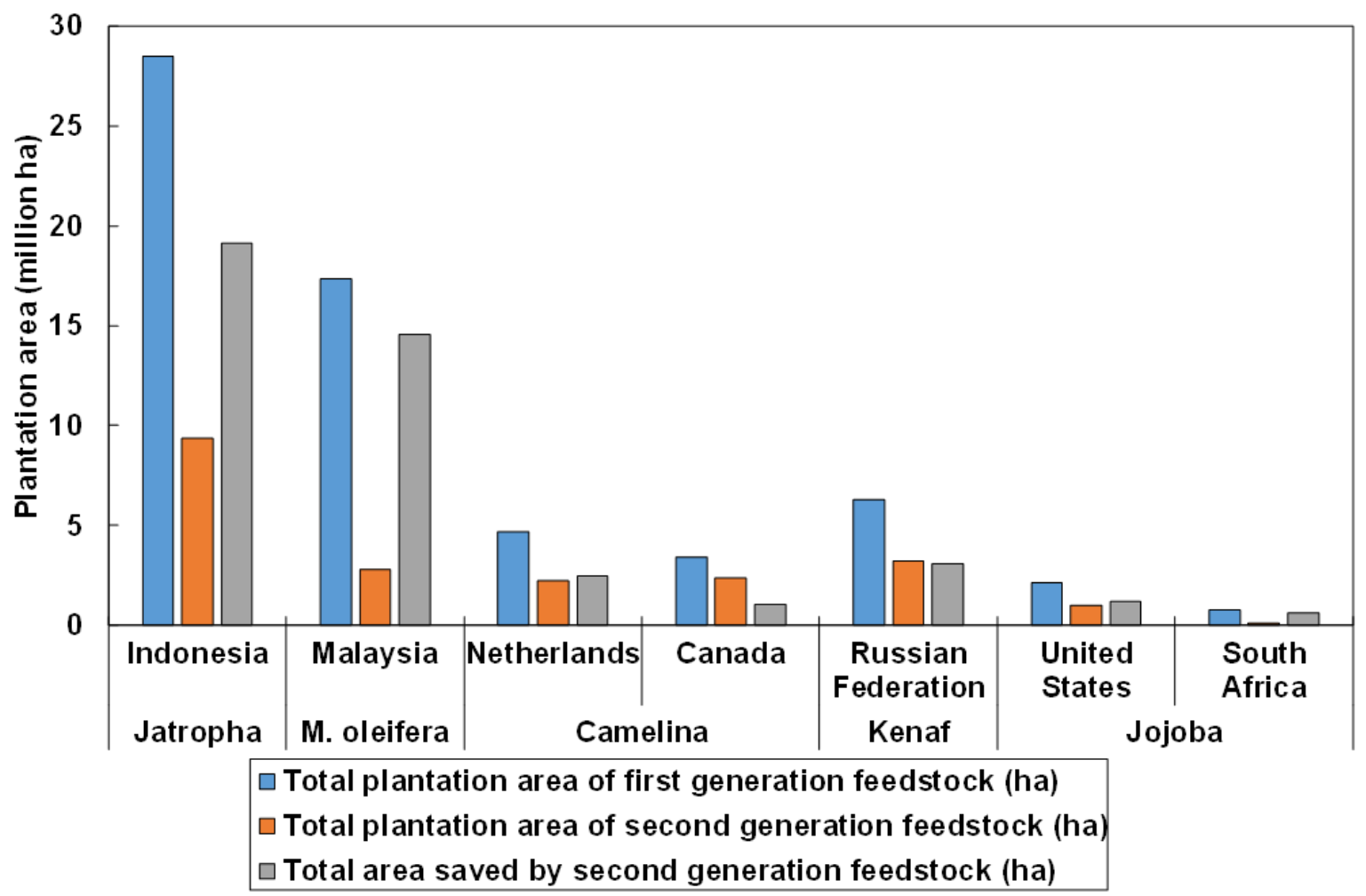

Figure 6: The area saved by replacing all first-generation feedstocks with second-generation feedstocks to produce equal volume of total potential biodiesel, regardless of profitability.

\section{Profitable potential biodiesel production}

\subsection{Government subsidy support}

With the current crude oil market and technologies, crude oil price fluctuates at about USD75/bbl (IndexMundi, 2017), and biodiesel can be produced at a refinery cost of USD0.1/L (Gomaa and Abed, 2017). At this situation, Benin, Ireland and Togo are the only countries that can increase biodiesel production profitably without governmental subsidy. In order to increase profitable biodiesel production, it is necessary for the government to provide subsidy to biodiesel industry. According to the combinations of feedstock availability-profitability for each country, different levels of subsidy is needed. As the subsidy increases, various feedstocks become profitable, thus, increase the profitable potential production that can be achieved. The subsidy required is calculated to match the profitability at different level of crude oil price. At crude oil price of USD75/bbl, the equivalent subsidy is zero. The 
equivalent subsidies at crude oil prices of USD110/bbl and USD160/bbl are USD0.28/L and USD0.67/L, respectively.

Table 3 lists the global proportion of feedstock used, as a percentage of total biodiesel volume the feedstocks can produce at zero subsidy, USD0.28/L and USD0.67/L. A subsidy of zero reflects the current profitability of biodiesel industry, where only 14 countries have potential for profitable production. Among the 10 feedstocks that can be used to produce profitable biodiesel, palm and rapeseed have lower feedstock cost. As palm has much higher quantity, it is the dominant feedstock at zero subsidy. At higher subsidy (USD0.28/L and above), palm remains the dominant profitable biodiesel feedstock. At subsidy of USD0.28/L, 66.67\% of the profitable biodiesel produced is palm biodiesel, and $57.38 \%$ at subsidy of USD0.67/L.

Table 3: Proportion of feedstock that could be used in global biodiesel production, in percentage of total feedstock, at zero subsidy and subsidies of USD0.28/L and USD0.67/L.

\begin{tabular}{lccc}
\hline & \multicolumn{3}{c}{ Proportion of feedstock use (\%) } \\
\cline { 2 - 4 } Feedstock & Subsidy $=0$ & Subsidy $=$ USD0.28/L & Subsidy = USD0.67/L \\
\hline Coconut & 0.00 & 0.00 & 0.05 \\
Cottonseed & 0.00 & 0.09 & 0.05 \\
Groundnut & 0.00 & 0.00 & 0.11 \\
Maize & 0.00 & 0.07 & 0.47 \\
Palm & 86.42 & 66.67 & 57.38 \\
Palm kernel & 0.00 & 0.00 & 3.58 \\
Rapeseed & 13.58 & 5.42 & 9.77 \\
Safflower & 0.00 & 0.00 & 0.03 \\
Soybean & 0.00 & 17.25 & 15.61 \\
Sunflower & 0.00 & 10.50 & 12.95 \\
\hline
\end{tabular}

Figure 7 shows the profitable potential biodiesel production $(P P B V)$ of 12 countries at different level of subsidies. These 12 countries have potential to produce at least 500 million litres of profitable biodiesel per annum at USD0.28/L subsidy, including Indonesia, Malaysia, Argentina, Ukraine, Canada, Russian Federation, the Netherlands, Brazil, Germany, Paraguay, Papua New Guinea and Guatemala, in descending order of the potential biodiesel production. It can be seen that, as subsidy 
increases from USD0.16/L to USD0.28/L, which is respectively equivalent to crude oil subsidy of USD20/bbl and USD35/bbl, these countries are able to increase the profitable potential biodiesel production by a range of 50 to 6800 million litres each year.

There are some countries that can achieve another leap in profitable potential biodiesel production with a smaller increment of subsidy, as a second feedstock becomes profitable. Argentina, Canada Germany and the Netherlands can experience a second jump in profitable production as subsidy increase from USD0.24/L to USD0.28/L. Likewise, Guatemala, Malaysia and Papua New Guinea could have a second jump when subsidy increase from USD0.43/L to USD0.51/L; and Indonesia from USD0.63/L to USD0.67/L.

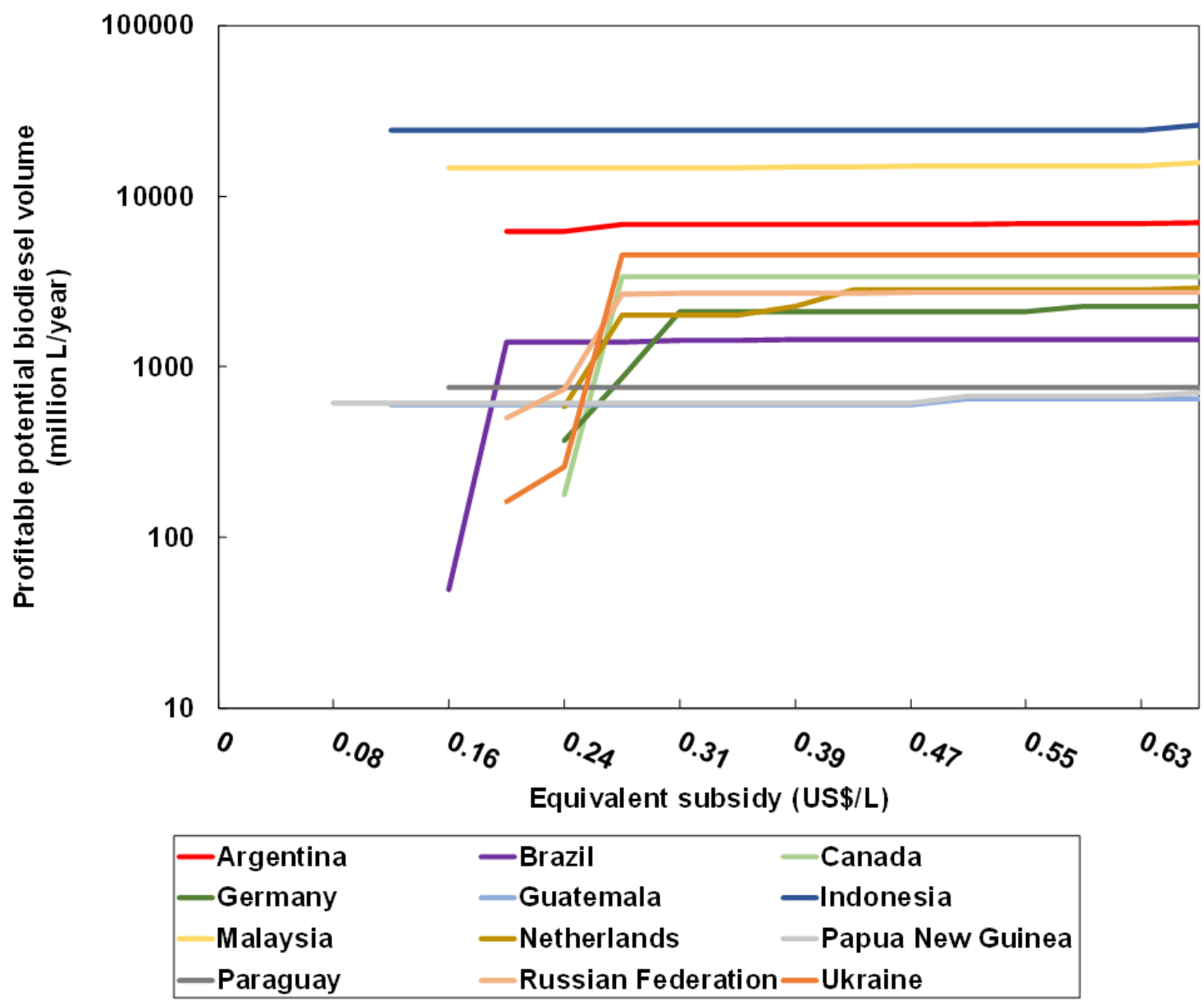

Figure 7: Profitable potential biodiesel volume that can be achieved with different subsidy for biodiesel production for the $\mathbf{1 4}$ countries with profitable potential biodiesel production higher than $\mathbf{5 0 0}$ million litres per annum at USD0.28/L subsidy. 
The provision of subsidies will aid the growth of the biodiesel industry to the point of gaining economies of scale. This will lead to long-term and sustained profitability of the industry, which will in turn provide tax revenues and possible export incomes. The inflow of revenue to governments will pay off the initial subsidies and also be used to support other relevant industry or grow the associated supply chain.

\subsection{Water stress}

Water input is required for biodiesel production, in both feedstock production and chemical conversion process of transesterification from oil to biodiesel. Each feedstock requires different amount of water to grow the crop, as well as to extract and refine the oil. Oil is then reacted with methanol to produce biodiesel. The water required during the production of methanol is the main water consumption for the reaction.

The water required for feedstock production in each country $\left(W R_{i j}\right)$ is calculated:

$$
W R_{i j}=E Q_{i j} \times W C_{i}
$$

where $W R_{i j}$ is the water requirement for each feedstock, $E Q_{i j}$ the export quantity of the feedstock and $W C_{i}$ the water consumption to produce the oil (Chapagain and Hoekstra, 2004; Mekonnen and Hoekstra, 2010). The water consumption includes the water used for agriculture and oil refinery.

The water used for methanol production $\left(M W R_{g j k}\right)$ is calculated:

$$
M W R_{g j k}=M W \times \frac{P P B V_{g j k}}{C R \times O M R}
$$

where $M W R_{g j k}$ represents the methanol water requirement, $M W$ the methanol water consumption and $O M R$ the oil-methanol ratio. One tonne of methanol is produced using $20 \mathrm{~m}^{3}$ of water on industrial scale, which is equivalent to a volumetric ratio of $15.744 \mathrm{~m}^{3}$ of water used per $\mathrm{m}^{3}$ of methanol produced (Romano and Sorichetti, 2011). A volumetric oil-methanol ratio of 8 is used (González et al., 2007; Yang and Jackson, 2012). This is approximated using the stoichiometry of transesterification. Methanol recovery process is considered in the production, thus, the actual reactants ratio of oil and methanol is used, instead of doubling the methanol input as used in the industry. The total water required is then calculated by summing up the water requirement of all profitable feedstocks and the methanol water requirement. 
The use of water in biodiesel production would introduce water stress in each country, to different levels, depending on the quantity of biodiesel produced and the water resource availability of the nation. Water stress index (WSI) is commonly used to indicate the water stress level of a region (Li et al., 2017). Each industry will contribute different portion to the final water stress in a country. The fraction of water stress index $\left(F W S I_{g j k}\right)$ contributed by biodiesel production is calculated:

$$
F W S I_{g j k}=\frac{T W R_{g j k}}{W A_{j}}
$$

where $T W R_{g j k}$ is the total water requirement and $W A_{j}$ is the water availability of each country, including precipitation and renewable water sources (FAO, 2014).

In order to increase the biodiesel blending ratio, certain volume of biodiesel needs to be produced according to the blending ratio to be achieved.
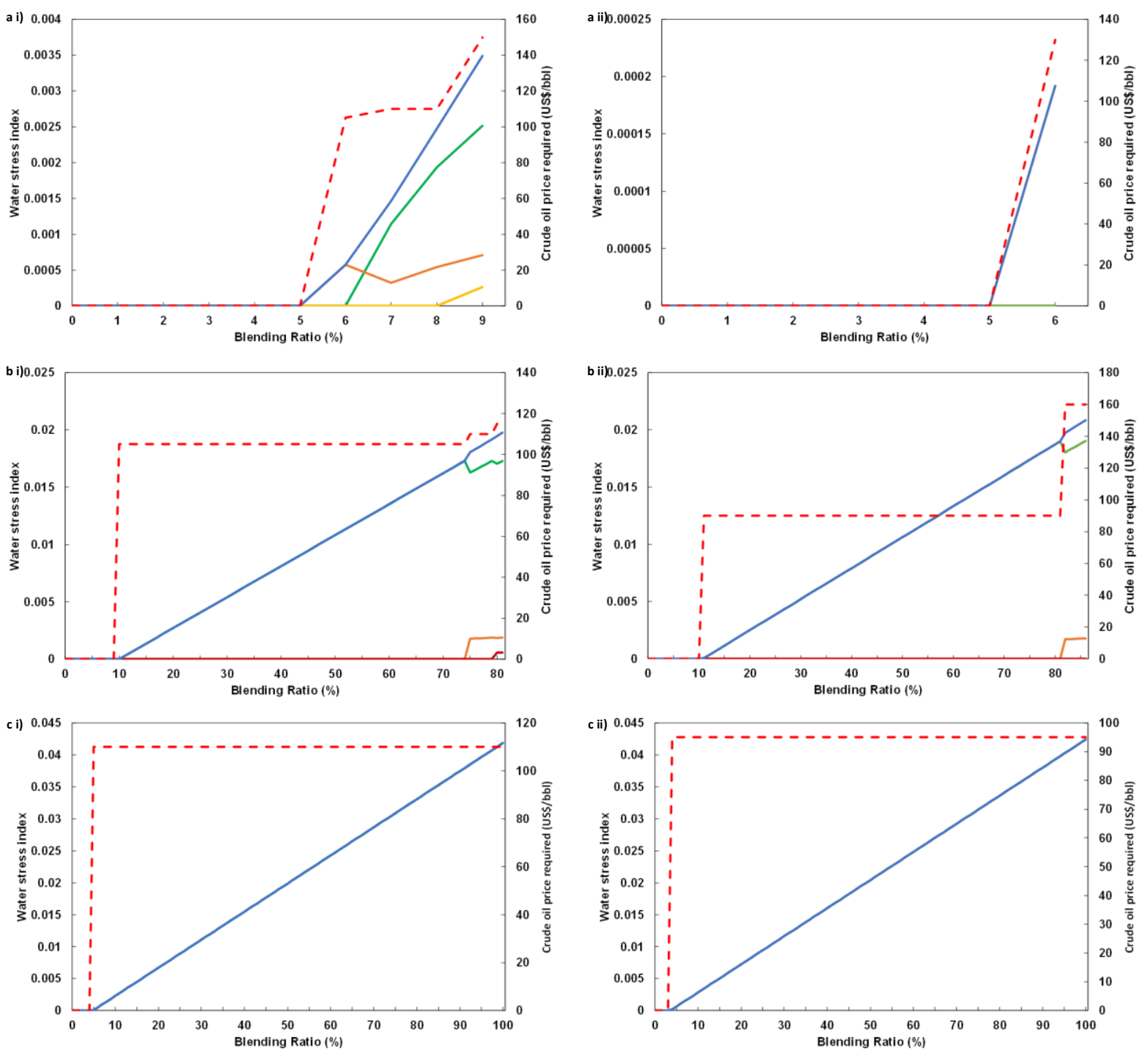

Palm — Palm kernel —Soybean —Coconut —WSI Fraction - -COP required 
Figure 8 shows the relationship between the total FWSI introduced by biodiesel production and the blending ratio, as well as the $F W S I$ for each feedstock used and the corresponding crude oil price required to achieve the blending ratio profitably in Thailand, Indonesia and Malaysia in 2013 and 2016. The relationship between FWSI and blending ratio is non-linear due to the versatility of the biodiesel production process to harness the use from various high-lipid feedstock. Each time a feedstock is added to the production, the rate of water requirement increment would change. Depending on the feedstocks available, biodiesel production increases the water stress to different extend.

Indonesia and Malaysia showed consistent trends in 2013 and 2016, while the relationship between FWSI and $B R$ for Thailand is more linear in 2016. The change in Thailand mainly results from the variation of feedstock price and available quantity over the years. In 2013, the feedstocks in Thailand had prices at multiple levels, which led to leaps in profitable potential biodiesel production at different COP level, as discussed in section 4.1. However, the feedstock available is much less in Thailand in 2016 (20\% of the amount as compare to that in 2013). Although Thailand can potentially achieve $6.57 \%$ blending ratio, only $6 \%$ is shown in the graph as a result of the model's resolution. At COP of US $\$ 140 / \mathrm{bbl}$, palm will share half of the potential production and at $C O P$ of $\mathrm{US} \$ 155 / \mathrm{bbl}$, the production will be $48 \%$ from palm kernel, $26 \%$ from soybean and $26 \%$ from soybean. The fully extended graph for Thailand in 2016 would have similar shape as 2013 (while the proportion of each feedstock will be different). 

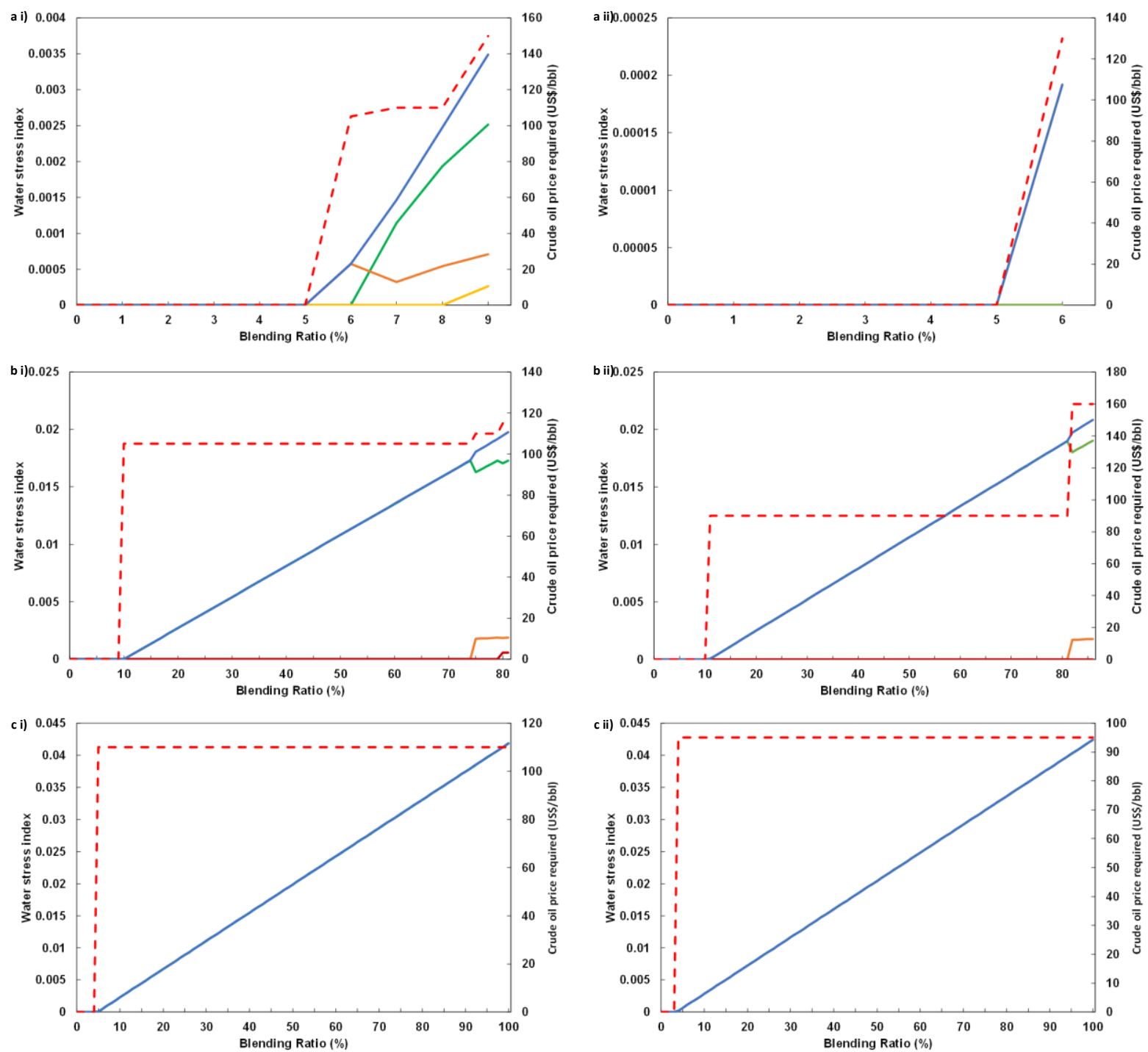

—Palm — Palm kernel — Soybean —Coconut —WSI Fraction - -COP required

Figure 8: The total fraction of WSI contributed by biodiesel production and fraction of WSI contributed by each feedstock at each biodiesel blending ratio in a i) Thailand in 2013, a ii) Thailand in 2016, b i) Indonesia in 2013, b ii) Indonesia in 2016, $c$ i) Malaysia in 2013 and $\mathrm{c}$ ii) Malaysia in 2016. The red dashed line indicates the corresponding crude oil price required to reach the blending ratio.

\subsection{Food stress}

The feedstocks for potential biodiesel production are considered only from the export market. The use of export-only feedstock will have the repercussions of disrupting the oil import supplies of other countries. This will invariably introduce various levels of food stress in other countries.

At current food market, most of the countries have sufficient supply in terms of average dietary energy supply adequacy (ADESA), as reported by the Committee on World Food Security (CFS) Round 
Table (CFS, 2016). However, the undernourished population all over the world has dietary energy supply (DES) of 100 to $400 \mathrm{Cal} / \mathrm{cap} /$ day less than the national average dietary energy requirement (FAO, 2000). The DES of the biodiesel feedstock used in each country is calculated:

$$
\begin{aligned}
D E S_{g j k} & =\frac{T E F_{g j k}}{\text { population }_{j} \times 365} \\
T E F_{g j k} & =\sum E F_{i j}
\end{aligned}
$$

where $T E F$ is the total energy of feedstock used for biodiesel production and $E F$ is the energy contained in the feedstock of each country. A country with larger population would have higher quota for biodiesel production on an absolute quantity basis.

Figure 9 shows the dietary energy of the potential biodiesel production at different blending ratios in Thailand, Indonesia and Malaysia in 2013 and 2016. The dietary energy supply is normalised on a per capita basis. Malaysia which has the capacity to totally replace diesel fuel consumption with biodiesel will divert the highest amount of food energy into fuel as compared to regional countries like Indonesia and Thailand. The diversion might spark a food vs fuel debate, but at the same time Malaysia is also facing an increasing inventory levels of palm oil. This transforms the conversation of crude palm oil market to be not of supply shortfall, instead an oversupply issue to be tackled. The production of biodiesel will potentially absorb the oversupply of palm oil. Thus, it is best to consider the circumstances of individual countries to evaluate the food diversion issues. 

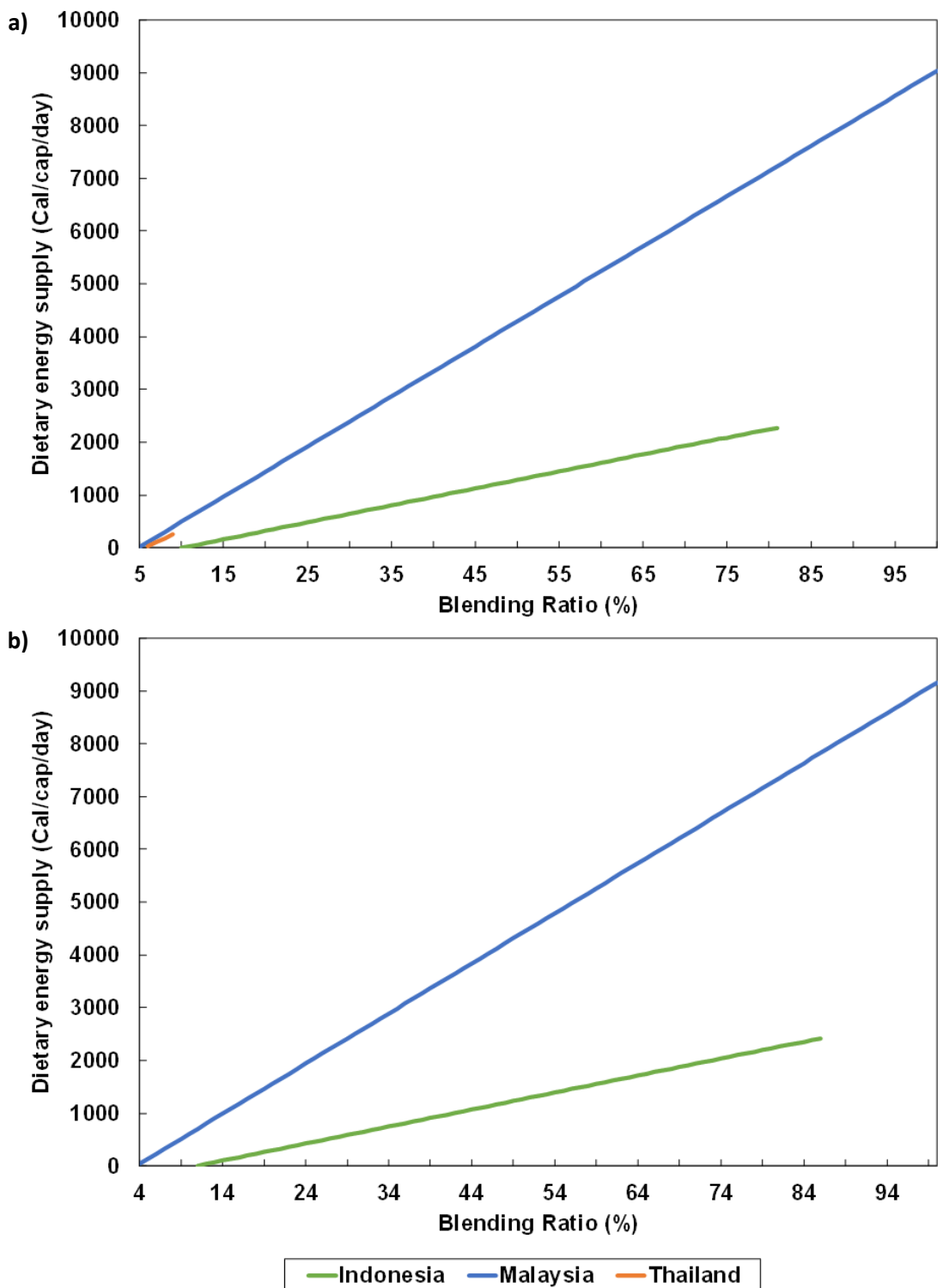

Figure 9: The dietary energy supply contained in the feedstocks used for biodiesel production in Thailand, Indonesia and Malaysia at each blending ratio in a) 2013 and b) 2016.

The percentage of population that can be fed by the feedstock is calculated in terms of fraction of ADESA (FADESA):

$$
F A D E S A_{g j k}=\frac{T E F_{g j k}}{\text { population }_{j} \times 365 \times A D E R_{j}}
$$

where $A D E R_{j}$ is the average dietary energy requirement of a country. $A D E R$ is calculated as a weighted average of the dietary energy requirement of each gender and age group (UNESCAP, 2013; UN, 2016). This calculation is based on the energy content of the feedstock, instead of the nutrition. Table 4 lists the percentage of population that can be fed by the feedstocks used for biodiesel production of 15 
countries, at zero subsidy and at subsidies of USD0.28/L and USD0.67/L. These 15 countries include the three countries that can profitably produce biodiesel at zero subsidy and the 12 countries that can produce more than 500 million litres of profitable biodiesel at subsidy of US $\$ 0.28 / \mathrm{L}$.

Table 4 Percentage of population of each country that can be fed by the profitable feedstock used for biodiesel production at zero subsidy, subsidies of USD0.28/L and USD0.67/L.

\begin{tabular}{lrrr}
\hline & \multicolumn{3}{c}{ Population (\%) } \\
\cline { 2 - 4 } Country & Subsidy $=0$ & $\begin{array}{r}\text { Subsidy }= \\
\text { USD0.28/L }\end{array}$ & $\begin{array}{r}\text { Subsidy }= \\
\text { USD0.67/L }\end{array}$ \\
\cline { 2 - 4 } Argentina & 0.00 & 160.77 & 164.06 \\
Benin & 4.48 & 4.48 & 4.48 \\
Brazil & 0.00 & 6.85 & 7.10 \\
Canada & 0.00 & 89.74 & 89.74 \\
Germany & 0.00 & 10.68 & 27.05 \\
Guatemala & 0.00 & 38.84 & 42.07 \\
Indonesia & 0.00 & 97.60 & 104.01 \\
Ireland & 2.49 & 2.49 & 2.49 \\
Malaysia & 0.00 & 494.97 & 528.30 \\
Netherlands & 0.00 & 122.12 & 173.20 \\
Papua New & & & \\
Guinea & 0.00 & 81.48 & 92.27 \\
Paraguay & 0.00 & 116.68 & 116.68 \\
Russian & & & 102.56 \\
Federation & 0.00 & 102.56 & \\
Togo & 4.77 & & 19.24 \\
Ukraine & 0.00 & & \\
\hline
\end{tabular}




\subsection{Limiting factor}

It is possible for all countries to replace $100 \%$ of diesel with biodiesel if there is enough feedstock. However, the environmental of the industry and security issues need to be taken into account. The production will be limited by four main factors, namely water stress, food stress, feedstock quantity and crude oil price.

Water stress is a crucial limiting factor of biodiesel production. It was reported that $8 \%$ of the global water resources is used for energy production (UNESCAP, 2013). By 2016, biofuels contribute $10 \%$ of the global primary energy (as seen in Figure 4) (IEA, 2015). A water stress index higher than 0.4 reflects high water stress (Raskin et al., 1997; Vörösmarty et al., 2000). With these three numbers, a maximum of 0.0032 for FWSI contributed by biodiesel production is set.

Food stress limit is set, so that if it is exceeded, there will be a possibility of increasing hunger level in countries where food sufficiency barely meets the requirement. The feedstock energy content that can provide $400 \mathrm{Cal} / \mathrm{cap} /$ day to the nation's population is set as the maximum of biodiesel production for each country. This limit can be used as an upper boundary of biodiesel production, to prevent catastrophic disruption of the global food market supply. Depending on the population of each country, the food stress limit will be different (in terms of total feedstock energy consumed).

Table 5 includes the maximum blending ratio permissible by the food stress and water stress limits for the 15 countries. The maximum blending ratio is calculated in two ways: 1 ) by $1 \%$ increment of blending ratio and calculate the corresponding $F W S I$ and $D E S$; and 2) by cumulatively taking individual feedstock one by one (in ascending order of the feedstock price) into biodiesel production and calculating the blending ratio that the country can reach, the FWSI and DES. 
Table 5: Maximum blending ratio that can be achieved by the 15 countries without exceeding the food stress and water stress.

\begin{tabular}{lcc}
\hline \multirow{2}{*}{ Country } & \multicolumn{2}{c}{ Maximum blending ratio (\%) } \\
\cline { 2 - 3 } Argentina & Food stress & Water stress \\
Benin & 26 & 30 \\
Brazil & 6 & 6 \\
Canada & 9 & 9 \\
Germany & 3 & 11 \\
Guatemala & 7 & 5.55 \\
Indonesia & 16 & 11 \\
Ireland & 23 & 22 \\
Malaysia & 1 & 1 \\
Netherlands & 7 & 10 \\
Papua New Guinea & 9 & 7 \\
Paraguay & 9 & 52 \\
Russian Federation & 6 & 37 \\
Togo & 9 & 7 \\
Ukraine & 11 & 9 \\
\hline
\end{tabular}

Besides food stress and water stress, feedstock is another factor that impedes the production of biodiesel. The price and available quantity of the feedstock will both affect the industry. Feedstock price determines the production cost and the corresponding subsidy that is required for biodiesel production. The quantity of feedstock limits the maximum potential volume of biodiesel produced, hence the maximum blending ratio a country can achieve.

It has been found that, out of the 155 countries investigated, biodiesel production of 82 countries would be primarily limited by feedstock quantity, 47 limited by crude oil price, 20 by water stress and 6 by food stress. Figure 10 shows the four limiting factors (feedstock quantity, crude oil price, water stress and food stress) for each of the countries investigated. Water stress will limit biodiesel production in most of the European countries and feedstock quantity will limit the production in Africa. It is worth mentioning that, biodiesel production in Indonesia would have dual-limiting factors. In the scope of this 
study, food stress would limit the biodiesel production in Indonesia to a volumetric blending ratio of $23 \%$, and water stress would limit it to $22 \%$.

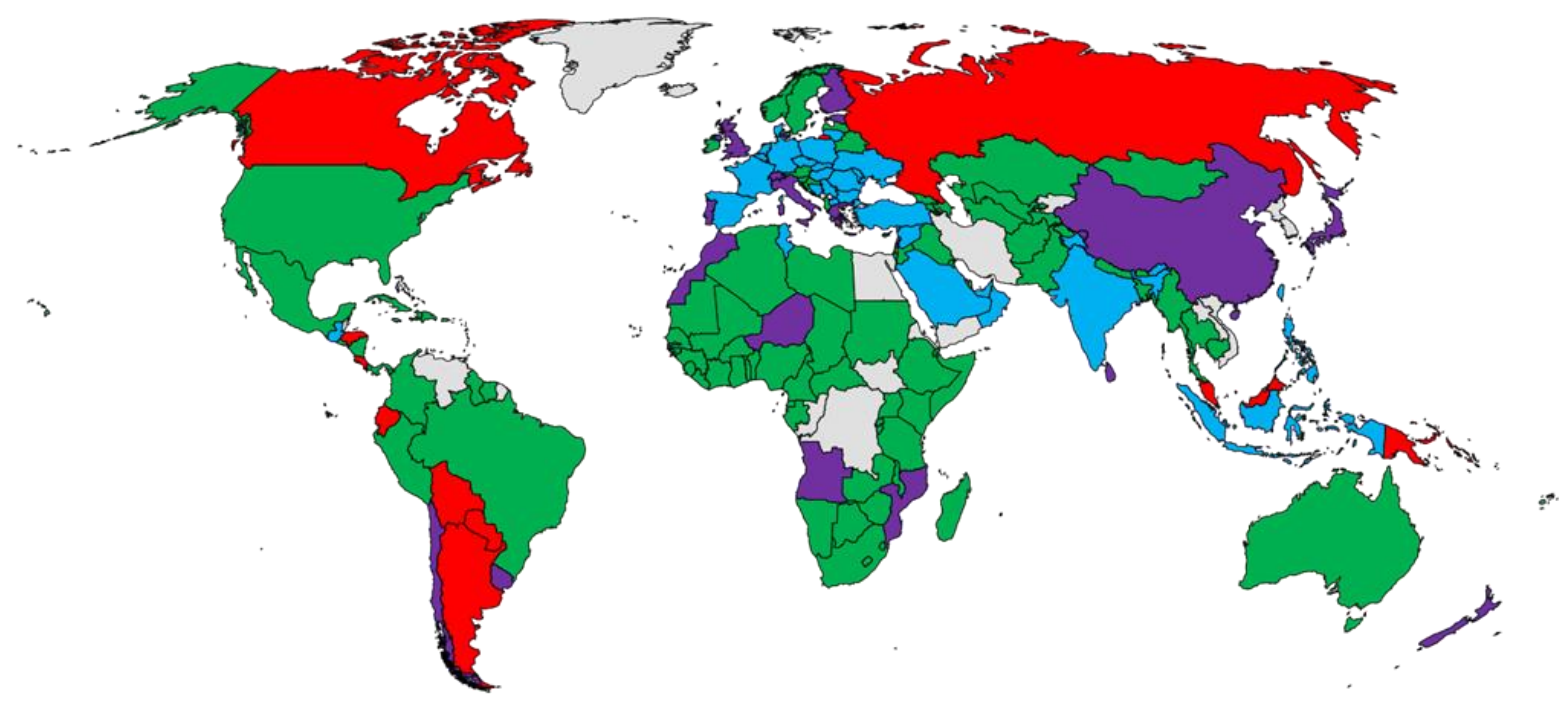

$\square$ Feedstock quantity $₫$ Crude oil price $₫$ Food stress $\square$ Water stress

Figure 10: Limiting factors for biodiesel production of 155 countries.

\section{Effect of biodiesel}

\subsection{Energy Security}

The production of biodiesel will affect the energy security of a country. In this study, short-term energy security and energy diversity are measured with a modified MOSES model (IEA, 2011), and Herfindahl-Hirschman Index (HHI) (World Energy Council, 2016; Kordanuli et al., 2017), respectively.

In the MOSES model, the short-term energy security of each country is evaluated with three parameters, including import dependence, entry points and volatility of agricultural output. These parameters represent the external risk, external resilience and domestic risk of biofuel industry, in that order. Each country is given a grade of A, B or C, which respectively indicates low, medium and high risk of the industry. The risk refers to the possible short-term disruptions that the energy system could experience and the capability of the system to recover from the disruptions. 
For the 45 countries with complete dataset, the short-term energy security was evaluated with potential biodiesel production. Figure 11 shows the short-term energy security grading of biodiesel industry with and without the addition of potential biodiesel production in 2013 and 2016. It can be seen that, out of the 45 countries, five countries have potential to improve the short-term energy security from grade $\mathrm{C}$ to $\mathrm{B}$, and one country from $\mathrm{B}$ to $\mathrm{A}$. These improvements generally occur in East Asian and European countries. With the addition of potential biodiesel, the biodiesel industry of these countries would be more invulnerable to short-term disruption.

a)

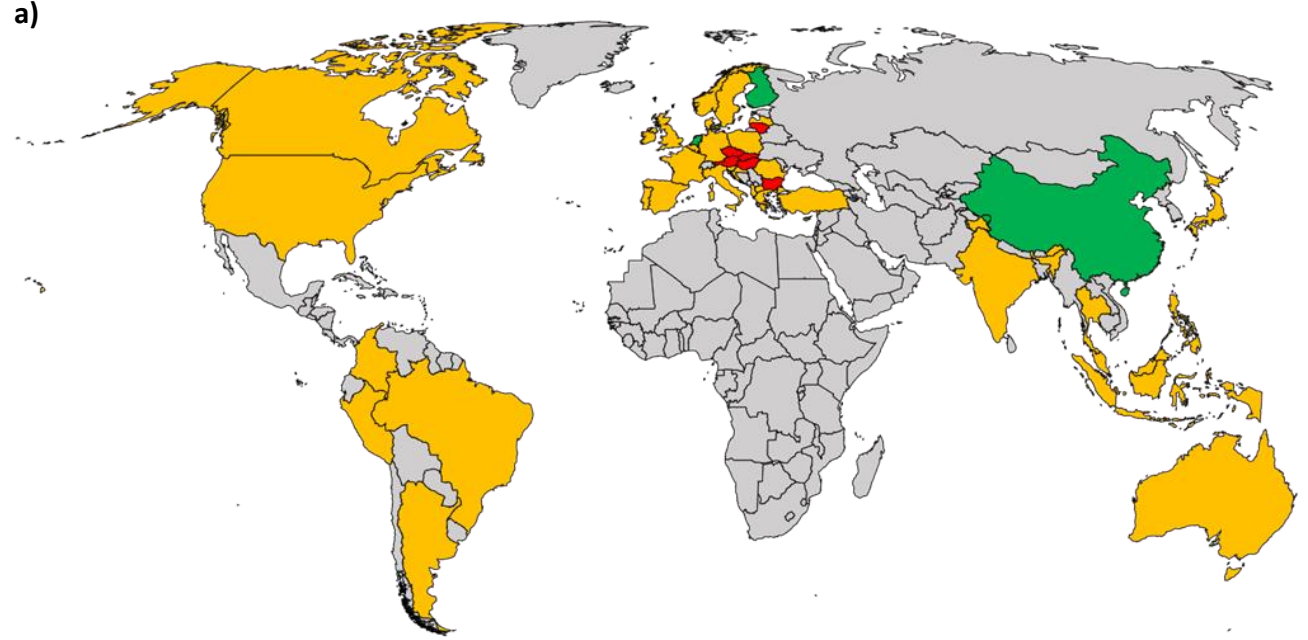

b)

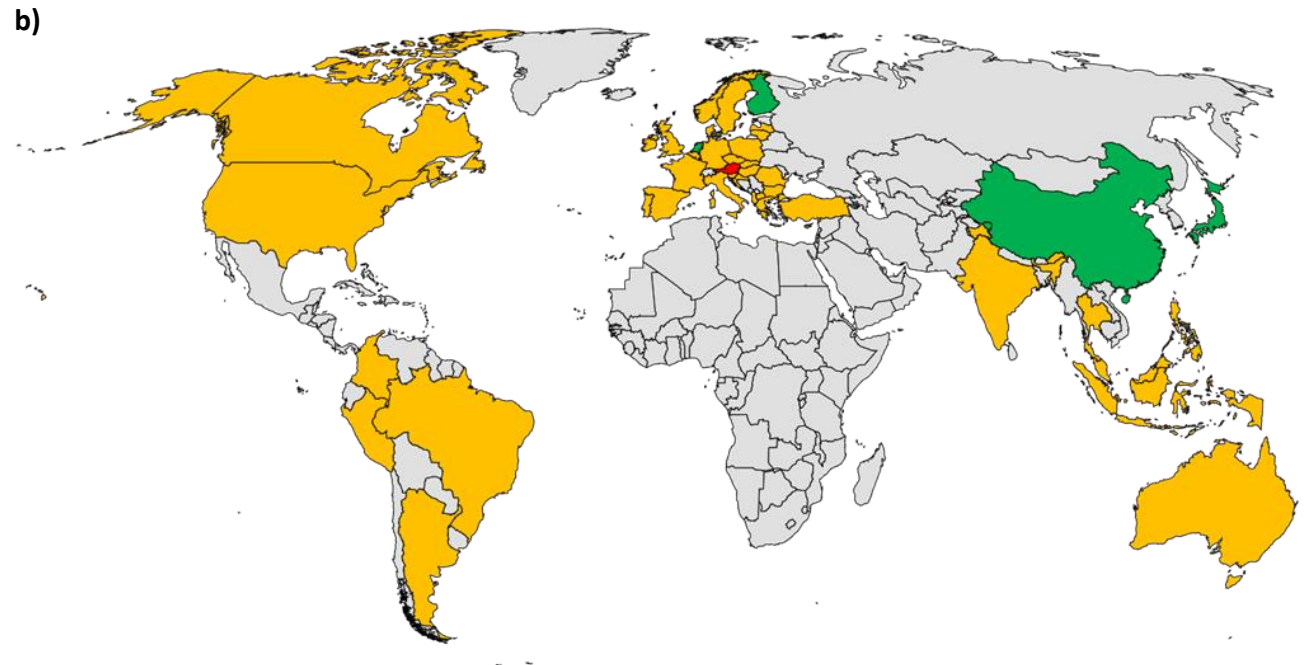

$\square \mathrm{A} \square \mathrm{B} \square \mathrm{C}$

Figure 11: Biodiesel industry short-term energy security category of countries a) at current biodiesel production and b) with potential biodiesel production. 
Addition of biodiesel production will also alter the energy diversity. The diversity of a country's primary energy is measured with the Herfindahl-Hirschman Index (HHI):

$$
H H I_{g j k}=\sum E S^{2}
$$

where ES is the primary energy source, as a percentage of total primary energy of each country, including coal, crude oil, oil products, natural gas, nuclear, hydro, geothermal and solar, and biofuels and waste. Lower HHI represents broader energy diversity. The energy of potential biodiesel production is added into biofuels and waste. Depending on the primary energy profile of each country, the energy diversity can potentially be improved or worsen. Figure 12 shows the HHI change with biodiesel blending ratio in Thailand, Indonesia and Malaysia.

Of the 84 countries with potential biodiesel feedstock investigated, 53 could broaden their energy diversity with potential biodiesel production. These include both developing and developed countries in all continents (UNSTATS, 2006). On the other hand, 23 countries would be reducing the energy diversity, including 12 countries located around the equatorial belt, as well as 11 European countries. The former group of countries have abundant biodiesel feedstock sources, such as palm and soybean. The European countries, including Germany and Italy, have already been promoting biodiesel as a greener, renewable alternative to diesel (Naylor and Higgins, 2017). These 25 countries were found to have a high usage of biofuel ( $25 \%$ to $99 \%$ of total primary energy), that the energy diversity would decrease with addition of potential biodiesel production. 


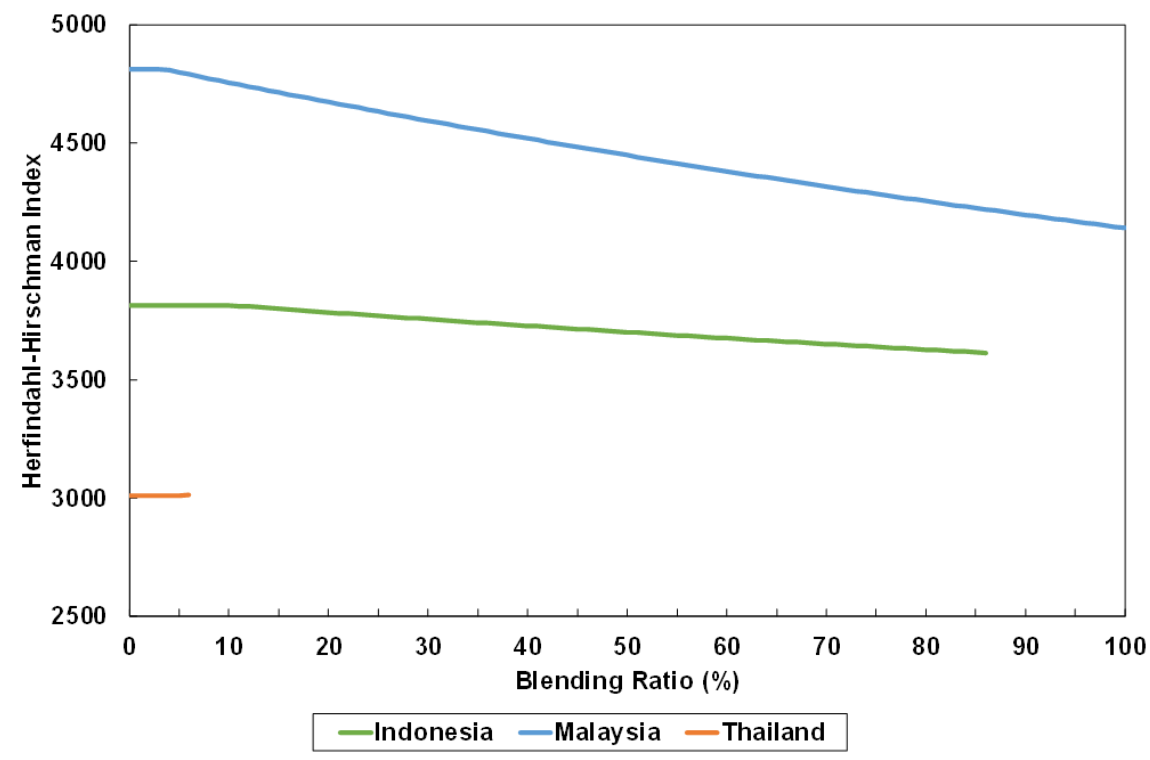

Figure 12: The HHI at each blending ratio achievable in Thailand, Indonesia and Malaysia.

\subsection{Emission}

Biodiesel is intended to be used as a cleaner alternative fuel to replace diesel. The emission properties of biodiesel differ from those of diesel, due to different chemical and physical properties. The NO, CO, unburned hydrocarbon (UHC) and smoke emission of biodiesel from each feedstock are compared with the emissions from diesel. The emissions were calculated using the fuel properties (Table 2) and the emissions predictor equation. Table 6 shows the predictor equations used to calculate each type of the emissions ( $\mathrm{Ng}, \mathrm{Ng}$ and Gan, 2012).

Table 7 shows the percentage difference of the four emissions from each biodiesel feedstock as compared to diesel emissions. All biodiesel, besides olive and rice bran biodiesel, show reduction in smoke opacity (by more than 20\%). Coconut biodiesel has reductions in all four types of emissions. Coconut biodiesel has high cetane number and oxygen content, and low kinematic viscosity and carbon residue. These properties make coconut biodiesel the cleanest first-generation biodiesel for use in the transportation sector. It has the most emission reduction in $\mathrm{CO}, \mathrm{UHC}$ and smoke opacity, and the second most reduction in $\mathrm{NO}$ emission. 
Table 6: The emission predictor equation coefficients of NO, CO, UHC and smoke opacity for the corresponding fuel property.

\begin{tabular}{|c|c|c|c|c|c|c|c|}
\hline $\begin{array}{l}\text { Type of } \\
\text { emission }\end{array}$ & Unit & $\begin{array}{l}\text { Cetane } \\
\text { number }\end{array}$ & $\begin{array}{l}\text { Kinematic } \\
\text { viscosity } \\
(\mathrm{mm} 2 / \mathrm{s})\end{array}$ & $\begin{array}{l}\text { Fuel } \\
\text { density } \\
(\mathrm{kg} / \mathrm{m} 3)\end{array}$ & $\begin{array}{l}\text { Carbon } \\
\text { residue } \\
(\%)\end{array}$ & $\begin{array}{l}\text { Oxygen } \\
\text { content } \\
(\%)\end{array}$ & Constant \\
\hline $\mathrm{NO}$ & $\begin{array}{l}\text { ppm by } \\
\text { vol }\end{array}$ & -1.8415 & & +0.0251 & & -0.0580 & +402 \\
\hline $\mathrm{CO}$ & $\%$ & $-1.30 \mathrm{E}-04$ & $+5.83 \mathrm{E}-04$ & $+1.04 \mathrm{E}-05$ & $-5.20 \mathrm{E}-04$ & & +0.0253 \\
\hline UHC & $\begin{array}{l}\text { ppm by } \\
\text { vol }\end{array}$ & -0.0162 & +0.3154 & -0.00015 & +1.4146 & -0.0197 & +3.1818 \\
\hline $\begin{array}{l}\text { Smoke } \\
\text { opacity }\end{array}$ & $\%$ & +0.0182 & +0.1944 & & +13.7769 & -0.1015 & +2.6283 \\
\hline
\end{tabular}

Table 7: Percentage change in NO, CO, UHC and smoke emission of each biodiesel as compared to baseline diesel emissions.

\begin{tabular}{lcccc}
\hline Feedstock & NO $(\%)$ & CO $(\%)$ & UHC $(\%)$ & Smoke opacity $(\%)$ \\
\hline Coconuts & -0.45 & -0.90 & -22.77 & -51.98 \\
Cottonseed & 7.30 & 9.50 & 5.71 & -37.98 \\
Groundnut & 6.36 & 8.92 & 8.61 & -21.16 \\
Kapok & 4.91 & 7.38 & 3.38 & -34.82 \\
Maize & 7.81 & 9.07 & 5.42 & -23.55 \\
Olives & 3.92 & 7.31 & 15.02 & 11.98 \\
Palm & -1.39 & 2.00 & -4.60 & -35.91 \\
Palm kernels & 5.24 & 3.52 & -12.49 & -31.44 \\
Rapeseed & 6.84 & 9.12 & 4.35 & -39.85 \\
Rice bran & 5.49 & 7.77 & 13.33 & 12.22 \\
Safflower & 8.25 & 9.00 & 3.69 & -24.37 \\
Sesame & 8.92 & 9.30 & 3.30 & -35.70 \\
Soybean & 8.74 & 9.36 & -0.76 & -45.14 \\
Sunflower & 8.18 & 9.89 & 6.17 & -31.60 \\
\hline
\end{tabular}

The possible emission changes by partially replacing diesel with the profitable potential biodiesel can be calculated. Figure 13 shows the emission changes by replacing diesel with profitable potential biodiesel at a subsidy of USD0.67/L in 12 countries. Smoke opacity will be reduced with the highest percentage in all countries with potential biodiesel production (nearly 50\% in Malaysia and over $30 \%$ in Argentina and Indonesia). UHC and NO emissions can be reduced in countries where coconut and/or palm biodiesel are dominant, such as Indonesia, Malaysia Papua New Guinea and Guatemala. UHC emission can also be reduced in countries with palm kernel as dominant feedstock of biodiesel, such as Thailand. 


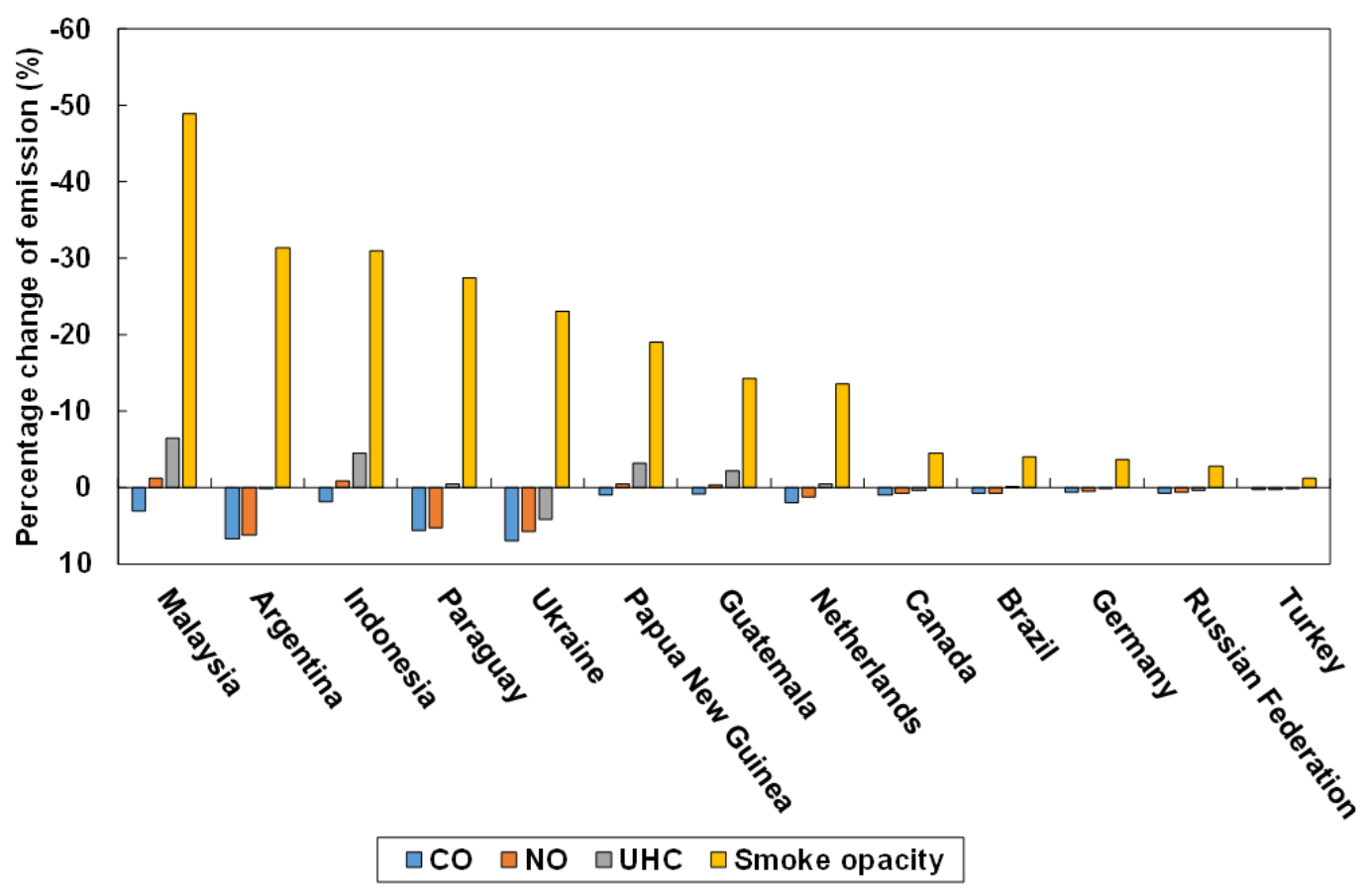

Figure 13: The percentage change of emission by replacing diesel with profitable potential biodiesel at subsidy of USD0.67/L.

\section{Conclusions}

This study focuses on the sustainability of biodiesel production in the energy-water-food (EWF) nexus, as well as the global impact of biodiesel as a renewable alternative fuel to diesel. The result shows that, with the potential first-generation biodiesel feedstocks, the renewable energy proportion in the global primary energy mix can increase by $0.43 \%$. Yet, biodiesel industry in most of the countries will be profitable only if there is governmental intervention in the form of subsidies. At a subsidy level of USD0.67/L, among the 84 countries with potential biodiesel feedstocks, 53 could broaden their energy diversity and 23 could be reducing the energy source variety. In terms of resource management from an EWF nexus perspective, the limiting factors curtailing biodiesel production in 82, 47, 20 and 6 countries are relating to the aspects of feedstock quantity, crude oil price, water stress and food stress, respectively. The major factor limiting the potential biodiesel production in Africa will be feedstock quantity, and water stress will be impeding the production in most of the European countries. It can be said that, feedstock quantity and crude oil price will be the factors that limit biodiesel production, and 
the biodiesel sustainability will be primarily impeded by water stress. The result of this study can serve as a guideline for governments to consider the feasibility and sustainability of biodiesel industry.

\section{Acknowledgement}

Financial support from the Malaysian Ministry of Higher Education's Fundamental Research Grant Scheme (FRGS/1/2016/TK07/USMC/02/2) is gratefully acknowledged.

\section{References}

Abbasi, S. and Diwekar, U. M. (2014) 'Characterization and stochastic modeling of uncertainties in the biodiesel production', Clean Technologies and Environmental Policy, 16(1), pp. 79-94. doi: 10.1007/s10098-013-0596-4.

Agarwal, A. K. (2007) 'Biofuels (alcohols and biodiesel) applications as fuels for internal combustion engines', Progress in Energy and Combustion Science, 33(3), pp. 233-271. doi: 10.1016/j.pecs.2006.08.003.

Altin, R., Cetinkaya, S. and Yucesu, H. (2001) 'Potential of Using Vegetable Oil Fuels as Fuel for Diesel Engines.', Energy Conversion and Management, 42, pp. 529-538.

Benjapornkulaphong, S., Ngamcharussrivichai, C. and Bunyakiat, K. (2009) 'Al2O3-supported alkali and alkali earth metal oxides for transesterification of palm kernel oil and coconut oil', Chemical Engineering Journal, 145(3), pp. 468-474. doi: 10.1016/j.cej.2008.04.036.

BP (2017) Primary Energy - 2017 in review. Available at: https://www.bp.com/en/global/corporate/energy-economics/statistical-review-of-worldenergy/primary-energy/energy-and-the-environment.html.

BP (2018) BP Statistical Review of World Energy.pdf. Available at: https://www.bp.com/en/global/corporate/energy-economics/statistical-review-of-worldenergy/oil/oil-reserves.html.

Budin, J. T., Breene, W. M. and Putnam, D. H. (1995) 'Some Compositional Properties of Camelina (Camelina sativa L. Crantz) Seeds and Oils', Journal of the American Oil Chemists' Society, 
72(3), pp. 309-315. doi: 10.1007/BF02523922.

Canoira, L. et al. (2010) 'Fatty acid methyl esters (FAMEs) from castor oil: Production process assessment and synergistic effects in its properties', Renewable Energy, 35(1), pp. 208-217. doi: 10.1016/j.renene.2009.05.006.

CFS (2016) Food_Security_Indicators, Committee on World Food Security. Available at: http://www.fao.org/economic/ess/ess-fs/ess-fadata/en/\#.Wb850K17GHo.

Chapagain, A. K. and Hoekstra, A. Y. (2004) Water Footprints of Nations. Available at: http://waterfootprint.org/media/downloads/Report16Vol2.pdf.

Chuah, T. G. et al. (2006) 'Biomass as the Renewable Energy Sources in Malaysia: An Overview', International Journal of Green Energy, 3(3), pp. 323-346. doi: 10.1080/01971520600704779.

Commission, E. (2016) Proposal for a DIRECTIVE OF THE EUROPEAN PARLIAMENT AND OF THE COUNCIL on the promotion of the use of energy from renewable sources. Available at: https://eur-lex.europa.eu/legal-content/EN/TXT/?uri=CELEX:52016PC0767R(01).

Cuberos Balda, M., Furubayashi, T. and Nakata, T. (2017) 'A novel approach for analyzing the foodenergy nexus through on-farm energy generation', Clean Technologies and Environmental Policy. Springer Berlin Heidelberg, 19(4), pp. 1003-1019. doi: 10.1007/s10098-016-1295-8.

Datta, A. and Mandal, B. K. (2017) 'A numerical study on the performance, combustion and emission parameters of a compression ignition engine fuelled with diesel, palm stearin biodiesel and alcohol blends', Clean Technologies and Environmental Policy. Springer Berlin Heidelberg, 19(1), pp. 157-173. doi: 10.1007/s10098-016-1202-3.

Day, C. and Day, G. (2017) 'Climate change, fossil fuel prices and depletion: The rationale for a falling export tax', Economic Modelling. Elsevier, 63(August 2016), pp. 153-160. doi: 10.1016/j.econmod.2017.01.006.

EIA (2014) Diesel consumption, US Energy Information Administration. Available at: https://www.eia.gov/beta/international/data/browser/\#/?pa=00000000004\&c=ruvvvvvfvtvnvv1 urvvvvfvvvvvvfvvvou20evvvvvvvvvnvvuvo\&ct=0\&tl_type=a\&tl_id=2-A\&vs=INTL.65-2AFG-TBPD.A\&cy=2013\&vo=0\&v=H\&start=1980\&end=2014 (Accessed: 23 June 2017).

EIA (2016) Biodiesel production, U.S. Energy Information Administration. doi: 10.1007/978-1-4020- 
5486-0_10.

EIA (2017) International Energy Outlook 2017. Available at: https://www.eia.gov/outlooks/ieo/.

Elms, R. D. and El-Halwagi, M. M. (2010) 'The effect of greenhouse gas policy on the design and scheduling of biodiesel plants with multiple feedstocks', Clean Technologies and Environmental Policy, 12(5), pp. 547-560. doi: 10.1007/s10098-009-0260-1.

Enerdata (2018) Global Energy Statistical Year Book 2018. Available at: https://yearbook.enerdata.net. FAO (2000) Undernourishment around the world - Depth of hunger: how hungry are the hungry?, FAO Corporate Document Repository. Available at: http://www.fao.org/docrep/x8200e/x8200e03.htm (Accessed: 2 September 2017).

FAO (2014) Aquastat Water availability, Aquastat. Available at: http://www.fao.org/nr/water/aquastat/data/query/results.html (Accessed: 30 June 2017).

FAO (2016a) Crop Yield, FAOSTAT. Available at: http://www.fao.org/faostat/en/\#data (Accessed: 16 July 2018)

FAO (2016b) Export Quantity, FAOSTAT. Available at: http://www.fao.org/faostat/en/\#data (Accessed: 20 July 2018).

FAO (2016c) Export Value, FAOSTAT. FAOSTAT. Available at: http://www.fao.org/faostat/en/\#data (Accessed: 20 July 2018).

Giakoumis, E. G. (2013) 'A statistical investigation of biodiesel physical and chemical properties, and their correlation with the degree of unsaturation', Renewable Energy. Elsevier Ltd, 50, pp. 858878. doi: 10.1016/j.renene.2012.07.040.

Gilron, J. (2014) 'Water-energy nexus: matching sources and uses', Clean Technologies and Environmental Policy, 16(8), pp. 1471-1479. doi: 10.1007/s10098-014-0853-1.

Gomaa, M. A. and Abed, R. M. M. (2017) 'Potential of fecal waste for the production of biomethane, bioethanol and biodiesel', Journal of Biotechnology. Elsevier, 253(February), pp. 14-22. doi: 10.1016/j.jbiotec.2017.05.013.

González, B. et al. (2007) 'Density, dynamic viscosity, and derived properties of binary mixtures of methanol or ethanol with water, ethyl acetate, and methyl acetate at $\mathrm{T}=(293.15,298.15$, and 303.15) K', Journal of Chemical Thermodynamics, 39(12), pp. 1578-1588. doi: 
10.1016/j.jct.2007.05.004.

Gui, M. M., Lee, K. T. and Bhatia, S. (2008) 'Feasibility of edible oil vs. non-edible oil vs. waste edible oil as biodiesel feedstock', Energy, 33(11), pp. 1646-1653. doi: 10.1016/j.energy.2008.06.002. Hamdan, S. H. et al. (2017) 'Influence of fatty acid methyl ester composition on tribological properties of vegetable oils and duck fat derived biodiesel', Tribology International, 113, pp. 76-82. doi: 10.1016/j.triboint.2016.12.008.

Hasan, A. H. and Avami, A. (2018) 'Water and emissions nexus for biodiesel in Iran', Renewable and Sustainable Energy Reviews. Elsevier Ltd, 93(May), pp. 354-363. doi: 10.1016/j.rser.2018.05.052.

Hoekman, S. K. et al. (2012) 'Review of biodiesel composition, properties, and specifications', Renewable and Sustainable Energy Reviews. Elsevier Ltd, 16(1), pp. 143-169. doi: 10.1016/j.rser.2011.07.143.

Hu, Z., Zhang, L. and Li, Y. (2017) 'Investigation of tall oil fatty acid as antiwear agent to improve the lubricity of ultra-low sulfur diesels', Tribology International. Elsevier Ltd, 114(April), pp. 5764. doi: 10.1016/j.triboint.2017.04.016.

IEA (2011) The IEA Model of Short-term Energy Security (MOSES) - Primary Energy Sources and Secondary Fuels. doi: 10.1787/5k9h0wd2ghlv-en.

IEA (2015) IEA Energy Report, IEA. Available at: http://www.iea.org/statistics/statisticssearch/report/?year=2014\&country=AUSTRALI\&produc $\mathrm{t}=$ Balances.

IEA (2017) Key World Energy Statistics 2018. Available at: https://webstore.iea.org/key-world-energystatistics-2017.

IndexMundi (2017) Diesel / Crude Oil (petroleum) Price Ratio, IndexMundi. Available at: http://www.indexmundi.com/commodities/?commodity=diesel\&months=120\&commodity=cru de-oil\&indicator=price-ratio (Accessed: 6 July 2017).

Irabien, A. and Darton, R. C. (2016) 'Energy-water-food nexus in the Spanish greenhouse tomato production', Clean Technologies and Environmental Policy. Springer Berlin Heidelberg, 18(5), pp. 1307-1316. doi: 10.1007/s10098-015-1076-9. 
Johnston, M. and Holloway, T. (2007) 'Policy Analysis A Global Comparison of National Biodiesel Production Potentials', Environmental Science and Technology, 41(23), pp. 7967-7973.

Karmakar, A., Karmakar, S. and Mukherjee, S. (2010) 'Properties of various plants and animals feedstocks for biodiesel production', Bioresource Technology. Elsevier Ltd, 101(19), pp. 72017210. doi: 10.1016/j.biortech.2010.04.079.

Kordanuli, B. et al. (2017) 'Appraisal of artificial neural network for forecasting of economic parameters', Physica A: Statistical Mechanics and its Applications, 465, pp. 515-519. doi: 10.1016/j.physa.2016.08.062.

Kumar, N., Varun and Chauhan, S. R. (2013) 'Performance and emission characteristics of biodiesel from different origins: A review', Renewable and Sustainable Energy Reviews. Elsevier, 21, pp. 633-658. doi: 10.1016/j.rser.2013.01.006.

Li, J. et al. (2017) 'Water shortages raised a legitimate concern over the sustainable development of the drylands of northern China: Evidence from the water stress index', Science of the Total Environment. Elsevier B.V., 590-591, pp. 739-750. doi: 10.1016/j.scitotenv.2017.03.037.

Lin, L. et al. (2009) 'Biodiesel production from crude rice bran oil and properties as fuel', Applied Energy. Elsevier Ltd, 86(5), pp. 681-688. doi: 10.1016/j.apenergy.2008.06.002.

Machacon, H. T. C. et al. (2001) 'Performance and emission characteristics of a diesel engine fueled with coconut oil - diesel fuel blend', Biomass and Bioenergy, 20(1), pp. 63-69. doi: 10.1016/S0961-9534(00)00059-3.

Mata, T. M. et al. (2011) 'Sustainability considerations of biodiesel based on supply chain analysis', Clean Technologies and Environmental Policy, 13(5), pp. 655-671. doi: 10.1007/s10098-0100346-9.

Mekonnen, M. M. and Hoekstra, A. Y. (2010) The Green, Blue And Grey Water Footprint Of Crops And Derived Crop Products. Available at: https://www.hydrol-earth-syst-sci.net/15/1577/2011/.

Muñoz, M. et al. (2011) 'Biodiesel improves lubricity of new low sulphur diesel fuels', Renewable Energy. Elsevier Ltd, 36(11), pp. 2918-2924. doi: 10.1016/j.renene.2011.04.007.

Myint, L. L. and El-Halwagi, M. M. (2009) 'Process analysis and optimization of biodiesel production from soybean oil', Clean Technologies and Environmental Policy, 11(3), pp. 263-276. doi: 
10.1007/s10098-008-0156-5.

Nabi, M. N. and Rasul, M. G. (2018) 'Influence of second generation biodiesel on engine performance, emissions, energy and exergy parameters', Energy Conversion and Management. Elsevier, 169(May), pp. 326-333. doi: 10.1016/j.enconman.2018.05.066.

Nations, U. (2015) Paris Agreement 2015. Available at: https://unfccc.int/process-and-meetings/theparis-agreement/the-paris-agreement.

Naylor, R. L. and Higgins, M. M. (2017) 'The political economy of biodiesel in an era of low oil prices', Renewable and Sustainable Energy Reviews. Elsevier Ltd, 77(February), pp. 695-705. doi: 10.1016/j.rser.2017.04.026.

Naylor, R. L. and Higgins, M. M. (2018) 'The rise in global biodiesel production: Implications for food security', Global Food Security. Elsevier B.V., 16(February 2017), pp. 75-84. doi: 10.1016/j.gfs.2017.10.004.

Ng, J. H., Ng, H. K. and Gan, S. (2012) 'Development of emissions predictor equations for a light-duty diesel engine using biodiesel fuel properties', Fuel. Elsevier Ltd, 95(x), pp. 544-552. doi: 10.1016/j.fuel.2011.12.049.

Nicolau, A. et al. (2014) 'The relation between lubricity and electrical properties of low sulfur diesel and diesel/biodiesel blends', Fuel. Elsevier Ltd, 117(PART A), pp. 26-32. doi: 10.1016/j.fuel.2013.09.026.

Noor, C. W. M. et al. (2016) 'An investigation of using biodiesel/marine diesel blends on the performance of a stationary diesel engine', Biomass and Bioenergy, 9(2), pp. 86-97.

O'Keeffe, S. et al. (2017) 'Modelling biodiesel production within a regional context - A comparison with RED Benchmark, Renewable Energy, 108, pp. 355-370. doi: 10.1016/j.renene.2017.02.024

Onay, O. (2007) 'Influence of pyrolysis temperature and heating rate on the production of bio-oil and char from safflower seed by pyrolysis, using a well-swept fixed-bed reactor', Fuel Processing Technology, 88(5), pp. 523-531. doi: 10.1016/j.fuproc.2007.01.001.

Rao, Y. V. H. et al. (2011) 'The effect of cottonseed oil methyl ester on the performance and exhaust emissions of a diesel engine', International Journal of Ambient Energy, 31(4), pp. 203-210. doi: 
10.1016/j.applthermaleng.2007.12.016.

Raskin, P. et al. (1997) Comprehensive Assessment Of The Freshwater Resources Of The World. Edited by K. Hultcrantz. Stockholm Environment Institute. Available at: https://www.ircwash.org/resources/comprehensive-assessment-freshwater-resources-world.

REN21 (2018) RENEWABLES 2018 GLOBAL STATUS REPORT. Available at: http://www.ren21.net/gsr-2018/.

Romano, S. D. and Sorichetti, P. A. (2011) 'Introduction to Biodiesel Production', in Dielectric spectroscopy in biodiesel production and characterization. Springer, pp. 7-27. doi: 10.1007/978-1-84996-519-4.

Russo, D. et al. (2012) 'State of the art of biofuels from pure plant oil', Renewable and Sustainable Energy Reviews. Elsevier Ltd, 16(6), pp. 4056-4070. doi: 10.1016/j.rser.2012.02.024.

Saladini, F. et al. (2016) 'Guidelines for emergy evaluation of first, second and third generation biofuels', Renewable and Sustainable Energy Reviews. Elsevier, 66(September 2015), pp. 221227. doi: 10.1016/j.rser.2016.07.073.

Sarve, A., Sonawane, S. S. and Varma, M. N. (2015) 'Ultrasound assisted biodiesel production from sesame ( Sesamum indicum L .) oil using barium hydroxide as a heterogeneous catalyst: Comparative assessment of prediction abilities between response surface methodology ( RSM ) and artificial neural network ', Ultrasonics - Sonochemistry. Elsevier B.V., 26, pp. 218-228. doi: 10.1016/j.ultsonch.2015.01.013.

Schober, S. and Mittelbach, M. (2004) 'The impact of antioxidants on biodiesel oxidation stability', European Journal of Lipid Science and Technology, 106(6), pp. 382-389. doi: 10.1002/ejlt.200400954.

Senthil Kumar, T., Senthil Kumar, P. and Annamalai, K. (2015) 'Experimental study on the performance and emission measures of direct injection diesel engine with Kapok methyl ester and its blends', Renewable Energy. Elsevier Ltd, 74, pp. 903-909. doi: 10.1016/j.renene.2014.09.022.

Sharma, Y. C. and Singh, V. (2017) 'Microalgal biodiesel: A possible solution for India's energy security', Renewable and Sustainable Energy Reviews. Elsevier, 67, pp. 72-88. doi: 
10.1016/j.rser.2016.08.031.

Silitonga, A. S., Ong, H. C., et al. (2013) 'Characterization and production of Ceiba pentandra biodiesel and its blends', Fuel. Elsevier Ltd, 108, pp. 855-858. doi: 10.1016/j.fuel.2013.02.014.

Silitonga, A. S., Masjuki, H. H., et al. (2013) 'Experimental study on performance and exhaust emissions of a diesel engine fuelled with Ceiba pentandra biodiesel blends', Energy Conversion and Management. Elsevier Ltd, 76, pp. 828-836. doi: 10.1016/j.enconman.2013.08.032.

Singh, S. P. and Singh, D. (2010) 'Biodiesel production through the use of different sources and characterization of oils and their esters as the substitute of diesel: A review', Renewable and Sustainable Energy Reviews, 14(1), pp. 200-216. doi: 10.1016/j.rser.2009.07.017.

Sinha, S., Agarwal, A. K. and Garg, S. (2008) 'Biodiesel development from rice bran oil: Transesterification process optimization and fuel characterization', Energy Conversion and Management, 49(5), pp. 1248-1257. doi: 10.1016/j.enconman.2007.08.010.

UN (2016) World Population Prospects, United Nations. Available at: https://esa.un.org/unpd/wpp/Download/Standard/Population/ (Accessed: 25 August 2017).

UNESCAP (2013) Water, Food and Energy Nexus in Asia and the Pacific. Available at: http://www.unescap.org/sites/default/files/Water-Food-Nexus Report.pdf.

UNSTATS (2006) Standard Country or Area Codes for Statistical Use. Available at: https://unstats.un.org/unsd/methodology/m49/.

USDA (2017) USDA GAIN Report, USDA Foreign Agricultural Service. Available at: https://gain.fas.usda.gov/Pages/Default.aspx.

Verma, P. and Sharma, M. P. (2016) 'Review of process parameters for biodiesel production from different feedstocks', Renewable and Sustainable Energy Reviews. Elsevier, 62, pp. 1063-1071. doi: 10.1016/j.rser.2016.04.054.

Viola, E., Zimbardi, F. and Valerio, V. (2011) 'Graphical method to select vegetable oils as potential feedstock for biodiesel production', European Journal of Lipid Science and Technology, 113(12), pp. 1541-1549. doi: 10.1002/ejlt.201000559.

Vörösmarty, C. J. et al. (2000) 'Global Water Resources: Vulnerability from Climate Change and Population Growth', Science, 289(5477), pp. 284-288. doi: 10.1126/science.289.5477.284. 
Whittington, T. (2006) BIODIESEL PRODUCTION AND USE BY FARMERS IS IT WORTH CONSIDERING ? Available at: http://bebioenergy.com/documents/Onfarmbiodieselprod.pdf.

World Coal Association (2018) Where is coal found?, World Coal Association. Available at: https://www.worldcoal.org/coal/where-coal-found.

World Energy Council (2016) World Energy Trilemma | 2016 ACCELERATE THE In Partnership with OLIVER WYMAN. Available at: http://www.worldenergy.org/publications/2016/world-energytrilemma-2016-defining-measures-to-accelerate-the-energy-transition/.

Xie, X. et al. (2017) 'Regional water footprints of potential biofuel production in China', Biotechnology for Biofuels. BioMed Central, 10(1), p. 95. doi: 10.1186/s13068-017-0778-0.

Yang, C. J. and Jackson, R. B. (2012) 'China's growing methanol economy and its implications for energy and the environment', Energy Policy. Elsevier, 41, pp. 878-884. doi: 10.1016/j.enpol.2011.11.037.

Živković, S. and Veljković, M. (2018) 'Environmental impacts the of production and use of biodiesel', Environmental Science and Pollution Research, 25(1), pp. 191-199. doi: 10.1007/s11356-0170649-z. 